\author{
Anna Carolina Milo Marasco
}

Avaliação genética do sistema reprodutivo dos

Pinguins-de-Magalhães (Spheniscus

magellanicus) através de análises de

paternidade

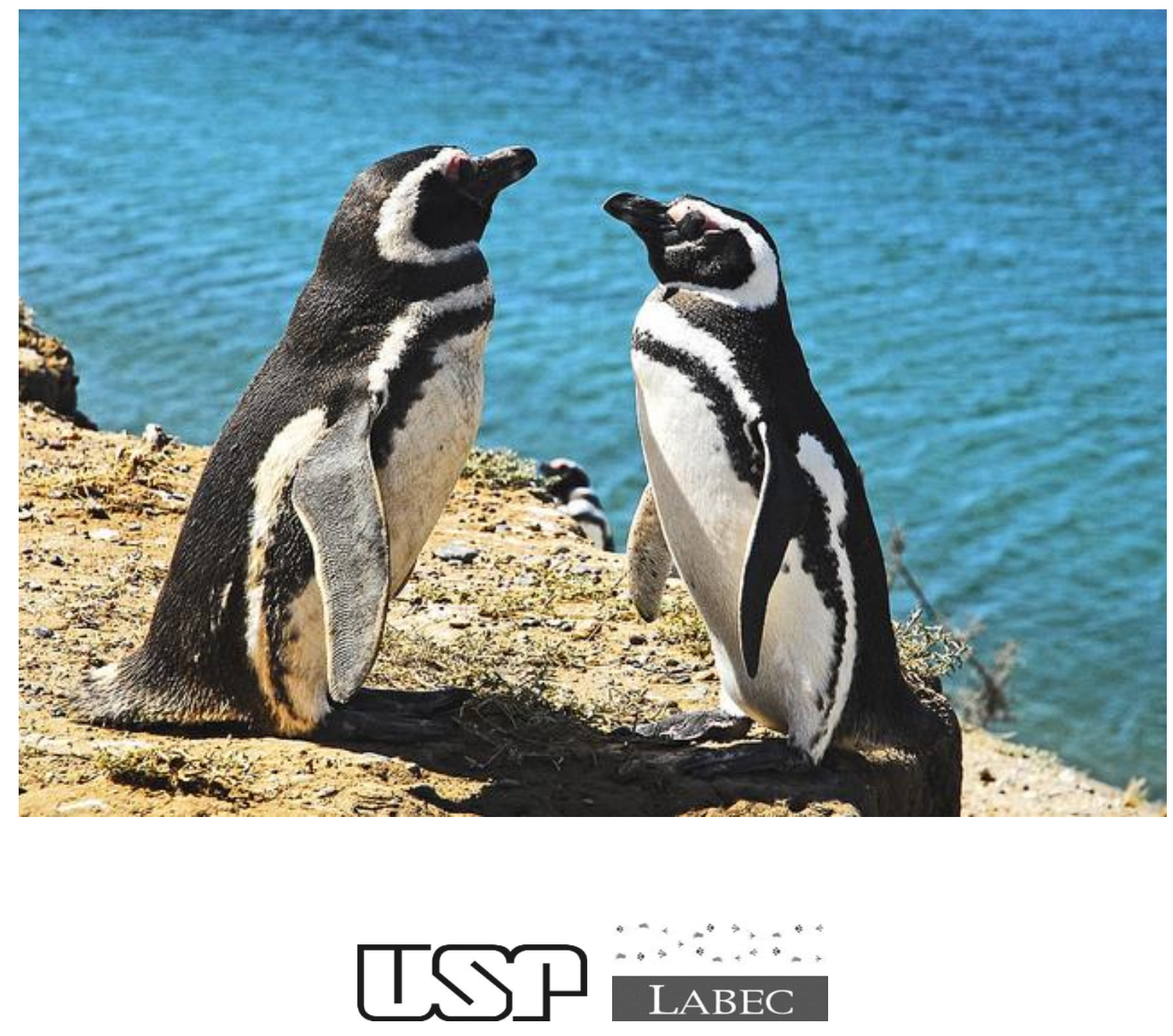

São Paulo 


\section{Avaliação genética do sistema reprodutivo dos \\ Pinguins-de-Magalhães (Spheniscus magellanicus) através de análises de paternidade}

Genetic evaluation of the reproductive system of Magellanic Penguins (Spheniscus magellanicus) through paternity analysis

Dissertação apresentada ao Instituto de Biociências da Universidade de São Paulo, para a obtenção de Título de Mestre em Biologia na Área de Genética.

Orientador: João Stenghel Morgante

Co-orientadora: Gisele Pires de Mendonça Dantas

São Paulo 
Marasco, Anna Carolina Milo

Avaliação genética do sistema reprodutivo dos Pinguins-

de-Magalhães (Spheniscus magellanicus) através de análises de paternidade

60 páginas

Dissertação (Mestrado) - Instituto de Biociências da Universidade de São Paulo. Departamento de Genética e Biologia Evolutiva

1. Paternidade extra-par 2. Spheniscus magellanicus 3. Microssatélites I. Universidade de São Paulo. Instituto de Biociências. Departamento de Genética e Biologia Evolutiva.

\section{Comissão Julgadora:}


Ao Prof. João Morgante 


\section{Agradecimentos}

Agradeço ao Prof. João por ter aberto as portas de seu laboratório para me receber e me ensinar tantas coisas. Para mim foi um prazer e uma honra ter feito parte da história do LABEC. Sou muito grata por todas as conversas, os conselhos, e por ter dividido seu vasto conhecimento e experiências de vida comigo.

Agradeço à Prof. ${ }^{a}$ Gisele por todos esses anos de dedicação, carinho e atenção. Independente da distância sempre se fez presente e atenciosa com meu trabalho e desempenho. Além de orientadora e amiga, se tornou um grande exemplo pra mim.

Há quase 6 anos eu entrei no LABEC, e foi nesse laboratório que eu cresci muito como pessoa e como pesquisadora. Cada pessoa que passou por lá me deixou algum tipo de aprendizado. Além dos meus orientadores, os meus companheiros de laboratório também foram grandes responsáveis pelo meu desenvolvimento. Por isso agradeço muito aos meus amigos que direta ou indiretamente contribuíram para o meu crescimento: Vanessa Simão, Gabriella Cardoso, Márcia Pincerati, Maria Helena, Juliana Ferreira, Rodrigo Francisco, Larissa Castro e, principalmente a Sofia Silva e Camila Clozato.

Agradeço à minha grande amiga e parceira Helena Tadiello, por todos esses anos de companheirismo. Desde 2007 que estudamos e trabalhamos juntas e, com certeza, a sua amizade transformou toda a minha vida em algo muito melhor.

Agradeço à minha família por todo cuidado, preocupação e carinho. Mesmo sem compreenderem bem esse mundo acadêmico, sempre desejam a minha realização pessoal e profissional. Agradeço especialmente ao meu irmão e melhor amigo, Rodrigo, por toda ajuda nos momentos mais intensos e complicados desses anos de Mestrado.

Agradeço ao meu namorado, Artur, que foi corajoso o bastante pra começar a namorar comigo mesmo na loucura que foi o final do Mestrado. Obrigada por sempre acreditar em mim, pela paciência, compreensão e companheirismo.

A realização deste trabalho só foi possível graças à colaboração com o Centro de Investigaciones Puerto Deseado (Argentina) e com os pesquisadores Melina Barrionuevo e Esteban Frere que realizaram a coleta e nos forneceram todas as amostras. Agradeço à bolsa de Mestrado concedida pela Coordenação de Aperfeiçoamento de Pessoal de Nível Superior (CAPES). 
$\begin{array}{ll}\text { Introdução Geral } & 07\end{array}$

$\begin{array}{ll}\text { 1. Sistemas de acasalamento } & 07\end{array}$

2. Monogamia em aves 08

3. Variações nas taxas de cópula e paternidade extra-par 09

4. Benefícios e riscos da cópula extra-par $\quad 11$

5. Ocorrência de cópula e paternidade extra-par em espécies de Pinguins 14

6. A espécie Spheniscus magellanicus 16

7. Análises de paternidade 19

$\begin{array}{ll}\text { Objetivos } & 23\end{array}$

Artigo - Molecular evidence of extra-pair paternity and intraspecific brood parasistism in Magellanic Penguins (Spheniscus magellanicus) 24

$\begin{array}{ll}\text { Abstract } & 24\end{array}$

$\begin{array}{lr}\text { Introduction } & 25\end{array}$

$\begin{array}{lr}\text { Material and Methods } & 29\end{array}$

$\begin{array}{ll}\text { Results } & 34\end{array}$

$\begin{array}{ll}\text { Discussion } & 39\end{array}$

$\begin{array}{ll}\text { Conclusion } & 44\end{array}$

$\begin{array}{ll}\text { Resumo } & 45\end{array}$

$\begin{array}{ll}\text { Abstract } & 47\end{array}$

$\begin{array}{ll}\text { Referências Bibliográficas } & 48\end{array}$ 


\section{Introdução Geral}

\section{Sistemas de acasalamento}

A reprodução é um processo biológico essencial para a perpetuação e conservação das espécies. A reprodução sexuada demanda um alto gasto de tempo e energia, mas tem grande importância evolutiva. Apesar de produzir um número menor de descendentes a cada geração, quando comparada com a reprodução assexuada, apresenta proles com maior variabilidade genética e, consequentemente, maiores chances de se adaptarem às diferentes condições sob a ação da seleção natural (Dunbrack et al., 1995; Freeman e Herron, 2009).

Dentro da reprodução sexuada existe uma variedade de relações reprodutivas entre os animais e, geralmente, os principais sistemas de acasalamento observados são: 1) Monogamia - associação entre um único macho e uma única fêmea que pode durar um ou mais ciclos reprodutivos; 2) poligamia - associação entre múltiplos machos e/ou fêmeas durante a estação reprodutiva que inclui a) poliandria associação de uma fêmea com dois ou mais machos; b) poliginia - associação de um macho com duas ou mais fêmeas; 3) poliginandria - ocorre quando dois ou mais machos têm uma relação exclusiva com duas ou mais fêmeas; 4) promiscuidade relação sexual indiscriminada, com ausência de qualquer vínculo social e, normalmente, de curta duração. (Wittenberger, 1979; Freeland, 2005) Estas relações não são fixas, já que os organismos podem apresentar mais de um destes sistemas de acasalamento, variando de acordo com as condições ambientais e/ou, com a distribuição de recursos (Freeland, 2005).

Tradicionalmente a classificação dos sistemas de acasalamento de uma espécie era realizada a partir de observações de cortejo, cópulas, companheiro de guarda e pelo cuidado parental. Apesar destas associações sociais entre os sexos poderem ser observadas, elas podem não refletir o real fluxo gênico entre os indivíduos da espécie (Westneat et al., 2010). Dessa forma, tornou-se necessário avaliar aspectos reprodutivos além dos padrões sociais entre machos e fêmeas (Lack, 1968; Selander, 1972; Emlen e Oring, 1977; Wittenberger, 1979), como os padrões transferência genética através das gerações (Wiley, 1974; Gowaty, 1985; Trail, 1985). 
O uso da biologia molecular tem possibilitado uma acurada inferência do comportamento reprodutivo das espécies, pois permitiu diferenciar entre sistemas de acasalamentos sociais, inferidos a partir da observação das interações entre os indivíduos, e sistemas de acasalamento genéticos, que refletem a relação biológica entre os pais e a prole (Freeland, 2005).

\section{Monogamia em aves}

Na maior parte dos grupos taxonômicos, é raro existir monogamia social, com exceção das aves, provavelmente devido à necessidade de um intenso cuidado biparental em muitas das espécies deste grupo (Freeland, 2005). Até algumas décadas atrás, acreditava-se que aproximadamente 93\% das espécies de aves apresentavam comportamento sexual monogâmico (Lack, 1968). Entretanto, a aplicação de técnicas moleculares levou a uma revolução na visão dos padrões de reprodução destes animais. Entre as espécies anteriormente consideradas monogâmicas somente $20 \%$ delas apresentaram monogamia verdadeira (Griffith et al., 2002), sendo a maioria, portanto, apenas socialmente monogâmica. Esses resultados demonstraram que, em muitos casos, os sistemas social e genético não coincidem devido à infidelidade (cópula extra-par) entre os parceiros sociais.

No caso das aves, os casais ("pares") são identificados, principalmente, pelas interações sociais entre os indivíduos adultos na fase de construção do ninho e posteriormente no cuidado biparental dos ovos e filhotes. Entretanto, existem casos em que um destes indivíduos copula com outro indivíduo diferente de seu parceiro de ninho (considerado o parceiro social), mas sem manter nenhuma outra interação além da cópula, determinando assim a cópula extra-par (Westneat et al., 2010). Além disso, estudos de observação comportamental revelaram que, geralmente, a cópula extrapar é solicitada pela fêmea e não forçada pelo macho (Kempenaers et al,. 1997; Currie et al., 1998).

Muitos dos estudos que visaram estimar as taxas de ocorrência das cópulas extra-par também se baseavam em observações comportamentais. Porém, este método pode fornecer estimativas pouco acuradas da real taxa de fertilização. (Westneat, 1987; Wink e Dyrcz, 1999; Griffiths et al., 2002). Isso porque a observação 
apresenta muitos fatores limitantes, como: a dificuldade de observar todas as cópulas que ocorrem; o fato de que a cópula extra-par pode ser visivelmente diferente da cópula entre o par, podendo gerar um viés nas estimativas de sua frequência; impossibilidade da visualização do órgão sexual da maior parte das aves, sendo difícil determinar se houve sucesso na transferência de esperma e, mesmo quando identificada a transferência, pouco se sabe sobre a competição espermática (Wink e Dyrcz, 1999). Portanto, a simples ocorrência da cópula extra-par não garante a fertilização das fêmeas. Dessa forma, para a genética, o importante não é a cópula extra-par em si, mas sim a fertilização, que pode ser mensurada por análises de determinação e exclusão de paternidade através do uso de marcadores moleculares.

\section{Variações nas taxas de cópula e paternidade extra-par}

A taxa de paternidade extra-par é definida como a proporção de fertilizações resultantes de cópulas entre indivíduos diferentes dos parceiros sociais reconhecidos pela classificação de sistemas de acasalamento tradicional (Westneat et al., 1990; Petrie e Kempenaers, 1998). Portanto, estas taxas podem variar entre as espécies de um mesmo gênero (Schulze-Hagen et al., 1993; Hasselquist et al., 1996), entre populações de uma mesma espécie (Gyllensten et al., 1990; Bjørnstad e Lifjeld, 1997) e, além disso, entre os anos de estudo de uma mesma população (Weatherhead e Boag, 1995).

Estudos evidenciaram que altas taxas de paternidade extra-par, estão geralmente relacionadas com fatores como alta taxa de mortalidade de adultos (Mauck et al., 1999; Wink e Drycz, 1999), cuidado parental reduzido (Gowaty, 1996; Birkhead e Moller, 1996; Moller, 2000; Bennet e Owens, 2002) e alta densidade populacional (Westneat et al., 1990; Petrie e Kempnears, 1998; Mayer e Pasinelli, 2012). A alta densidade populacional gera uma maior proximidade entre os indivíduos, aumentando as chances de encontro e oportunidade de acasalamento, reduzindo assim os custos para engajar em uma cópula extra-par (Gowaty e Bridges, 1991; Mayer e Pasinelli, 2012).

Entretanto, existem também alguns comportamentos que buscam evitar a cópula extra-par, como por exemplo, o comportamento de guarda dos parceiros 
sociais que impedem a aproximação de outros machos (Birkhead, 1996; Wagner et al., 1996). Outra estratégia relatada na literatura é a realização de cópulas frequentes durante o período fértil das fêmeas, garantindo assim a paternidade da prole do pai social, mesmo se ocorrer cópulas extra-par (Møller, 1987; Mougeot, 2004).

Trabalhos evidenciaram altas taxas de paternidade extra-par, principalmente entre passeriformes (eg. Emberiza schoeniclus Dixon et al., 1994; Turdus migratorius Briskie e Montgomery, 1997; Vireo olivaceus Morton et al., 1998; Malurus cyaneus Dunn e Cockburn, 1999), sendo que a espécie mais promíscua encontrada até hoje foi a Ammodramus caudacutus (pardal do sapal) que apresentou 93\% de paternidade extra-par, ou seja, em quase todos os 62 ninhos analisados existia pelo menos um indivíduo proveniente da cópula entre a fêmea e um macho diferente de seu parceiro social (Hill et al., 2010).

Os poucos estudos com aves não passeriformes existentes indicam baixas taxas de cópula extra-par que raramente levam a casos de paternidade extra-par. (e.g., Decker et al., 1993; Warkentin et al., 1994; St Clair et al., 1995; McLean et al., 2000). Aves marinhas são animais de vida longa, que exibem alto investimento no cuidado biparental e apresentam parâmetros de história de vida e de reprodução semelhantes, como a vida em colônias, monogamia social, e pouco ou nenhum dimorfismo sexual (Quillfeldt, et al., 2012). Esse grupo, em particular, tem demonstrado baixas taxas de paternidade extra-par, possivelmente devido ao intenso cuidado biparental necessário para a prole sobreviver em um ambiente de recursos alimentícios imprevisíveis (Hunter et al., 1992; Mauck et al., 1995; Austin e Parkin, 1996; Birkhead e Møller, 1996; Dearborn et al., 2001). Entretanto, até o ano de 2012, menos de $10 \%$ das quase 450 espécies de aves marinhas existentes tinham sido estudadas em relação à paternidade extra-par (Quillfeldt et al., 2012). Dentre as espécies estudadas, a taxa mais alta encontrada foi em Larus ridibundus (guincho-comum), que apresentou 33\% de ninhos com pelo menos um filhote sendo resultado de paternidade extra-par (Lezalová-Pialková, 2011). 


\section{Benefícios e riscos da cópula extra-par}

As altas taxas de paternidade extra-par encontradas nas espécies de aves trouxeram muitas questões sobre quais seriam as vantagens adaptativas para este tipo de comportamento sexual (Griffiths et al., 2002). Geralmente, a variação no sucesso reprodutivo é mais pronunciada em sistemas de acasalamento poligâmicos, mas também pode variar em sistemas monogâmicos onde ocorrem cópulas extra-par (Webster et al. 1995; Kempenaers et al., 1997; Møller, 1998; Dunn e Cockburn 1999; Whittingham e Dunn, 2000).

Os benefícios da cópula e fertilização extra-par variam entre os machos e as fêmeas. Para os machos, a cópula extra-par tende a elevar diretamente a taxa de reprodução de cada indivíduo, devido ao aumento do número de prole que eles deixam ao longo das gerações (Wink e Dyrcz, 1999). Em um sistema completamente monogâmico, o sucesso reprodutivo dos machos seria limitado (Goossens et al., 1998) e, por isso, seria vantajoso para o macho manter seu cuidado parental para a prole com sua parceira social, mas também engajar em cópulas extra-par para fertilizar mais fêmeas (Trivers, 1972). Entretanto, a procura pela cópula extra-par envolve também alguns riscos como, por exemplo, o aumento no risco de traição (já que ao sair em busca de uma nova cópula, a sua fêmea fica livre para copular com outros machos), o aumento do gasto energético pela busca de um novo par e maior risco de transmissão de doenças (Birkhead e Moller, 1992; Sheldon, 1994).

No caso das fêmeas, os benefícios e custos da cópula extra-par são muito discutidos e ainda permanecem pouco claros (Griffiths et al., 2002). Em geral, eles são classificados como diretos ou indiretos (Westneat et al., 1990; Birkhead e Møller 1992; Petrie et al., 1998; Petrie e Kempenaers 1998; Wink e Dyrcz, 1999). Os diretos, ou não genéticos, são aqueles que aumentam as chances de sobrevivência (defesa contra predadores, obtenção de recursos providos pelos machos) ou de garantia de fecundação da fêmea (Kirkpatrick e Ryan, 1991; Wolf, 1975; Lifjeld et al., 2007). Os benefícios indiretos, ou genéticos, estão relacionados com as novas combinações genéticas geradas pela paternidade extra-par (Jennions e Petrie, 2000; Zeh, e Zeh, 2001). Isso porque, sistemas reprodutivos como a poliandria, que envolvem mais de dois indivíduos, tendem a apresentar uma prole com maior variabilidade genética, 
quando comparada a proles de acasalamentos monogâmicos, podendo aumentar o fitness da prole e fornecer vantagem evolutiva para a espécie em questão (Jennions e Petrie, 2000). Entretanto, os benefícios genéticos gerados pela ocorrência de cópula extra-par podem ser difíceis de serem identificados, pois sua magnitude pode variar de acordo com as condições ambientais sendo muitas vezes camufladas por essas (Schmoll et al., 2003; Garvin et al., 2006; Arct et al., 2013).

Alguns estudos demonstraram que o endocruzamento pode ser uma força importante que dirige a evolução do comportamento de acasalamento extra-par apresentado pelas fêmeas (Blomqvist et al., 2002; Foerster et al., 2003). A homozigose, favorecida pelo endocruzamento, aumenta a probabilidade da expressão de alelos deletérios, o que aumenta a incidência de doenças, ou mesmo, reduz a sobrevivência dos indivíduos (Bensch et al., 1994; Kempenaers et al,, 1996; Tregenza e Wedell, 2002; Foerster et al., 2003). Porém, a ocorrência de paternidade extra-par aumenta os níveis de heterozigose e, consequentemente, o valor reprodutivo da prole.

Além disso, uma hipótese aceita e que também explica a evolução e manutenção do comportamento extra-par feminino é a dos "bons genes" ("good genes"). De acordo com esta hipótese, as fêmeas são capazes de aumentar a qualidade genética e o valor reprodutivo de parte de sua prole ao engajar em cópulas extra-par com machos de maior qualidade genética que seu parceiro social (Westneat et al., 1990; Birkhead e Møller 1992; Petrie e Kempenaers, 1998; Leech et al, 2001; Griffith et al., 2002). Estes bons genes podem estar ligados, por exemplo, com a geração de filhotes extra-par de maior tamanho (Dreiss et al., 2008), com melhor sistema imune (Arct et al., 2013) ou com maior capacidade de reprodução (Tschirren et al., 2012).

Em muitas espécies a razão sexual (proporção de machos e fêmeas) observada é de 1:1. Isso porque machos e fêmeas devem contribuir igualmente para a ascendência das gerações posteriores, ou seja, investem igualmente em cada sexo (Fisher, 1930). Mas, de acordo com a teoria da alocação (Charnov, 1982; Trivers and Willard, 1973), a seleção natural pode favorecer os indivíduos que possuem a habilidade de enviesar a reprodução em direção ao sexo de maior valor reprodutivo. O mecanismo de alocação do sexo nas aves ainda não foi completamente descoberto (Krackow, 1995). Anteriormente acreditava-se que a variação da razão sexual nas aves era resultado apenas da segregação cromossômica aleatória durante a meiose 
(Williams, 1979). Entretanto, estudos recentes evidenciaram que a relação dos sexos a cada ninhada pode ser enviesada de maneira adaptativa em relação a uma variedade de fatores, tais como as condições físicas da fêmea (Hornfeldt et al, 2000; Nager et al, 1999), características sexuais secundárias dos machos (Ellegren et al., 1996; Sheldon et al, 1999), disponibilidade de recursos e competição (Wiebe and Bortolotti 1992; Komdeur et al, 1997; Korpimaki et al 2000).

Além disso, razões sexuais secundárias enviesadas para os machos foram encontradas em algumas espécies monogâmicas em que foi confirmada a ocorrência de paternidade extra-par (Svensson e Nilsson 1996; Bradbury e Blakey 1998; Kölliker et al 1999; Whittingham e Dunn, 2000; Johnson et al, 2009). Alguns autores sugerem que as fêmeas são capazes de influenciar na razão sexual de sua ninhada, podendo aumentar seu próprio fitness ao gerar uma prole enviesada para o sexo masculino entre os filhotes extra-par. Isso porque as fêmeas engajariam em cópulas extra-par com machos de maior qualidade que seu parceiro social, e os filhotes machos poderiam apresentar maior valor reprodutivo que filhotes fêmeas (Burley, 1986; Burley e Calkins, 1999; Whittingham e Dunn, 2000).

Assim como para os machos, a cópula extra-par também envolve alguns custos e riscos para as fêmeas. Além da maior exposição a doenças e parasitas, elas podem sofrer com retaliações físicas e comportamentais. Em algumas espécies, após a cópula extra-par, a fêmea pode ser agredida por seu parceiro social (Barash, 1976). Já em outras, a retaliação por parte do macho pode ser na diminuição do cuidado parental com a prole (Petrie e Kempenears, 1998). Sendo assim, espera-se que altas taxas de cópula e paternidade extra-par estejam relacionadas com espécies em que a redução do cuidado parental pouco influencia na sobrevivência da prole, ou nas que as fêmeas são capazes de cuidar de seus filhotes com pouca ajuda de seus parceiros sociais, pois podem correr o risco da diminuição de cuidado parental (Birkhead e Møller, 1996; Gowaty, 1996; Petrie e Kempenears, 1998). 


\section{Ocorrência de cópula e paternidade extra-par em espécies de Pinguins}

Pinguins (ordem: Sphenisciforme) são aves marinhas não voadoras que compõe um grupo de 18 espécies que habitam a região do hemisfério Sul. Algumas características da biologia reprodutiva são comuns entre as diversas espécies de pinguins como, por exemplo, a filopatria, a fidelidade a um parceiro (com o qual se reencontra e se reproduz a cada estação reprodutiva), e o intenso cuidado biparental. Dessa forma, espera-se que estas aves apresentem comportamento estritamente monogâmico e taxas de cópula e paternidade extra-par insignificantes (Pilastro et al., 2001).

Poucos trabalhos focaram na avaliação do comportamento de cópula e paternidade extra-par dos pinguins. Das 18 espécies existentes, 7 foram estudadas em relação à ocorrência de cópula extra-par, sendo que até hoje apenas 5 tiveram seus sistemas de acasalamento estudados sob o ponto de vista genético (tabela 1), através da técnica de DNA fingerprinting (minissatélites). Apesar de não ser esperada a infidelidade entre os casais de pinguins, estes estudos demonstraram que algumas espécies apresentam cópulas e paternidade extra-par nas populações estudadas.

Tabela 1. Estudos genéticos sobre o sistema de acasalamento de diferentes espécies de pingüins usando DNA fingerprinting (\%EPP - porcentagem de filhotes extra-par, \%Ninhos EPP - porcentagem de ninhos estudados que apresentaram pelo menos um filhote sendo extra-par, N - número de ninhos estudados) - Adptado de Quillfeldt et al. (2012)

\begin{tabular}{c|cccc}
\multicolumn{1}{c}{ Espécies } & $\begin{array}{c}\text { \% } \\
\text { EPP }\end{array}$ & \% Ninhos EPP & N & Referência \\
\hline Spheniscus humboldti & 0 & - & 21 & Schwartz et al. (1999) \\
Eudyptes schlegeli & $3.8 \%$ & $7.7 \%$ & 13 & St Clair et al. (1995) \\
Eudyptes pachyrhynchos & 0 & - & 24 & McLean et al. (2000) \\
Pygoscelis adeliae & $9.1 \%$ & $11.1 \%$ & 18 & Pilastro et al. (2001) \\
Pygoscelis antarticus & 0 & - & 38 & Moreno et al. (2000)
\end{tabular}


Hunter et al. (1995) observaram que aproximadamente $10 \%$ das fêmeas dos Pinguins-Adélia (Pygoscelis adeliae) na Ilha Ross, Antártica, engajavam em cópula extra-par. Nesta mesma colônia, Hunter e Davis (1998) observaram que as fêmeas desta espécie se envolvem em cópula extra-par em troca de material para a construção de seus ninhos. Tanto os machos quanto as fêmeas coletam pequenas pedras no chão ao redor de seu território para a construção dos ninhos, criando uma plataforma na qual as fêmeas põem seus ovos e, por isso, a procura por este material é alta. Além disso, é comum indivíduos roubarem pedras dos ninhos vizinhos (Sladen, 1958) e, quando isso acontece eles são recebidos com um comportamento agonístico pelo pinguim presente no local (Spurr, 1975). Entretanto, foi observado que, quando a fêmea pegava uma pedra de um ninho vizinho após engajar em cópula extra-par com o macho residente, nenhum comportamento agressivo ocorria. Dessa forma, elas eram capazes de voltar diversas vezes ao mesmo ninho para coletar mais pedras, sem sofrer qualquer tipo de impedimento ou agressão, e voltavam imediatamente para seu parceiro e seu próprio ninho, onde depositavam o material (Hunter e Davis, 1998). Posteriormente, Pilastro et al. (2001) analisaram a paternidade de 22 filhotes de $P$. adeliae da colônia em Victoria Land, Antártica, e encontrou que cerca de $9 \%$ deles eram resultado de cópulas extra-par, corroborando o padrão observado por Hunter et al. (1995) e Hunter e Davis (1998). Já para outra espécie do mesmo gênero, os Pinguins-de-barbicha (Pygoscelis antarticus), não foi encontrado nenhum caso de paternidade extra-par nos 38 ninhos analisados da colônia da llha Deception, Antártica (Moreno et al., 2000).

Schwartz et al. (1999) observaram que $31 \%$ das fêmeas e $19 \%$ dos machos de 21 ninhos dos Pinguins-de-Humboldt (Spheniscus humboldti) da colônia em Punta San Juan, Peru, engajavam em cópulas extra-par. Entretanto suas análises genéticas não acusaram nenhum caso de paternidade extra-par, indicando que a fertilização não foi bem sucedida. Hood (1996) afirma que, apesar de ter observado 509 cópulas entre os Pinguins-de-Magalhães (Spheniscus magellanicus) em Punta Tombo, Argetina, (Argentina), não evidenciou nenhum caso extra-par.

Os indivíduos da espécie Eudyptes pachyrhynchus (Pinguim-de-Fiordland) da colônia das Ilhas Open Bay, Nova Zelândia, apresentaram tanto monogamia social quanto genética, pois das 24 famílias estudadas em nenhuma delas foi encontrado 
casos de filhotes extra-par (McLean et al., 2000). O mesmo padrão foi observado para outra espécie do gênero, Eudyptes schlegeli (Pinguim-real) em uma colônia da Georgia do Sul, por Olsson et al. (2001) onde não encontraram nenhum caso de cópula ou paternidade extra-par nos seis anos de estudo. Além disso, St. Clair et al. (1995) avaliaram indivíduos dessa mesma espécie, Eudyptes schlegeli, na Ilha Macquarie, Austrália, e demonstraram que dos 26 filhotes analisados, apenas um não era filhote de seu pai social.

Dessa forma, apesar da constatação das cópulas extra-par, em muitos casos a taxa de fertilização extra-par resultante é baixa ou inexistente. Além disso, parece haver uma variação entre os gêneros e até mesmo entre espécies do mesmo gênero.

\section{A espécie Spheniscus magellanicus}

Dentro desse contexto, este projeto buscou avaliar os mecanismos reprodutivos dos Pinguins-de-Magalhães (Spheniscus magellanicus) através de uma abordagem de genética molecular. Apesar de ter tido seu comportamento sexual observado (Hood, 1996), este é o primeiro estudo genético realizado com a espécie que foca em sua biologia reprodutiva e que poderá avaliar mais profundamente o sistema reprodutivo dos Pinguins-de-Magalhães, a partir da avaliação da existência e frequência de paternidade extra-par.

A espécie S. magellanicus (Forster,1781) ocorre na costa Pacífica e Atlântica da América do Sul, distribuindo-se desde a Ilha Algarrobo (Chile) até a costa central da província do Rio Negro (Argentina), incluindo as Ilhas Falklands/Malvinas (Williams 1995, Simeone et al. 2003) (Figura 1A). Estes pinguins, apesar de nadarem grandes distâncias, ainda são muito dependentes da terra para sua reprodução, que ocorre em colônias ao longo da costa sul da América do Sul (entre $29^{\circ} \mathrm{S}$ ao longo da costa do Oceano Pacífico, a cerca de Tierra del Fuego e na costa Atlântica norte a $42^{\circ} \mathrm{S}$, incluindo as Ilhas Falkland), durante o período de Setembro à Abril (Williams, 1995) (Figura 1B). 

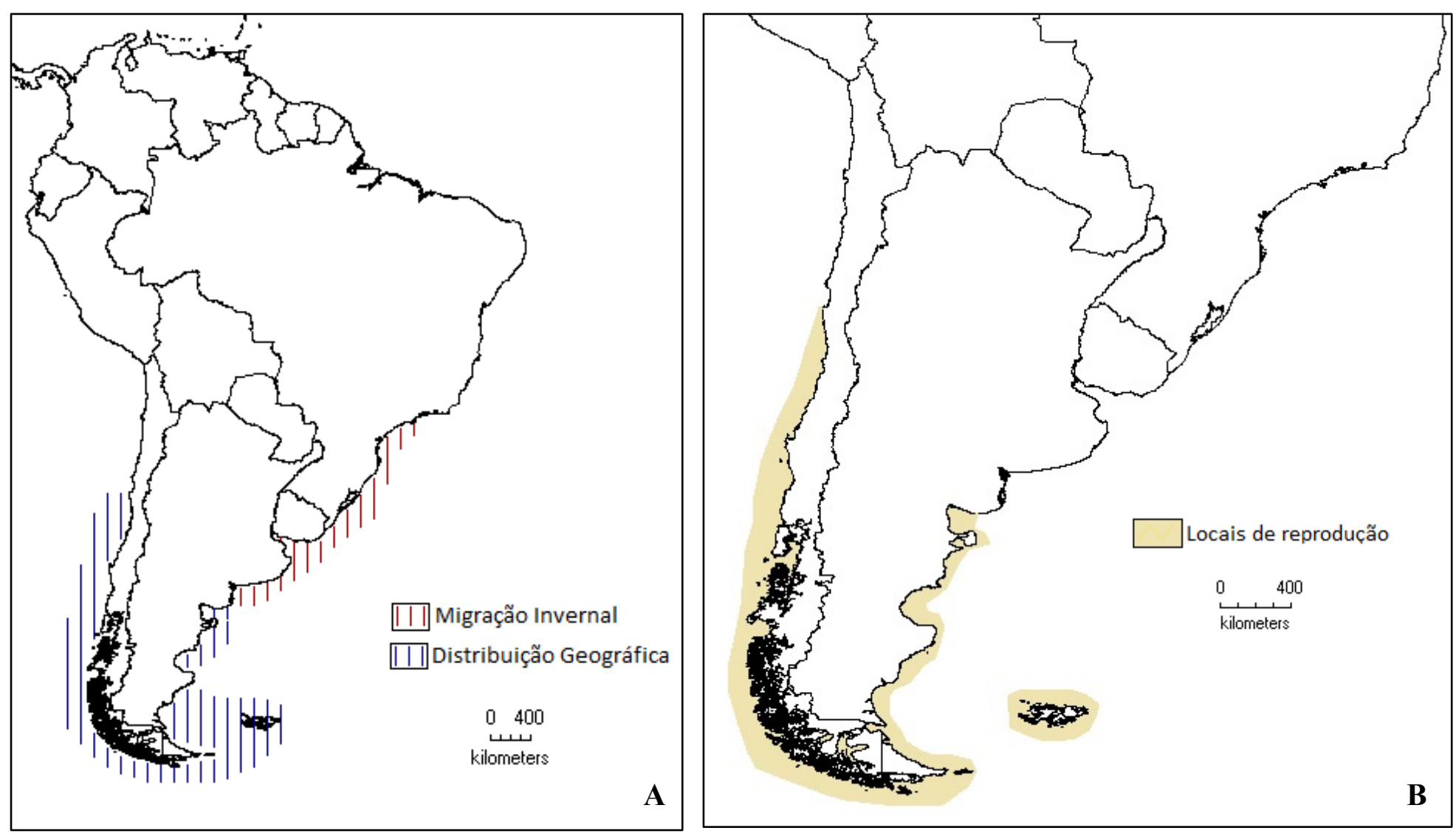

Figura 1 - (A) Distribuição geográfica e dispersão durante a migração invernal dos Pinguins de Magalhães; (B) Locais de reprodução dos Pinguins-de-Magalhães

Esta espécie não apresenta dimorfismo sexual, apesar de alguns trabalhos buscarem identificar o sexo dos indivíduos adultos através de características morfológicas de tamanho de bico, aleta e peso indicando que os machos são relativamente maiores (Scolaro et al., 1983; Bertellotti et al., 2002), nem variação sazonal e são filopátricos (Boersma, 2008).

As fêmeas dos Pinguins-de-Magalhães entram na idade reprodutiva entre 4 e 5 anos de idade e os machos entre 6 a 7 anos (Willians, 1995), mantendo-se ativos sexualmente aproximadamente até os 11 anos de idade. 
Estes pinguins chegam às suas colônias em setembro, quando ocorre o reencontro dos casais (parceiros que se reproduziram nas estações reprodutivas anteriores). A fidelidade entre os pares de um ano para o outro varia de acordo com o sucesso reprodutivo. Divórcios são observados quando o casal não teve sucesso na estação reprodutiva anterior, trocando de parceiro no ano seguinte (Fowler, 1993). O registro de maior fidelidade na espécie foi de um casal da colônia de Punta Tombo, Argentina, que permaneceu junto por 17 anos consecutivos, até que um dos indivíduos não retornou mais para a colônia (Borboroglu e Boersma, 2013). Geralmente os machos chegam antes, iniciando a ocupação dos ninhos e a proteção do território (Sick 1997, Stokes e Boersma 1998). Os ninhos dos Pinguins-de-Magalhães são feitos debaixo de arbustos ou em covas escavadas no solo (Frere et al., 1992, Stokes e Boersma 1998).

Em outubro, ocorre a postura de maneira sincronizada, de no máximo dois ovos por ninhada, que são incubados alternadamente pelos pais durante cerca de 40 dias (Stokes e Boersma, 1998). Em um primeiro momento, o macho realiza a viagem de forrageamento, que dura aproximadamente duas semanas, enquanto a fêmea incuba os ovos e permanece sem se alimentar. Após o retorno do macho, as fêmeas também viajam em busca de alimentação, e os machos ficam responsáveis por incubar os ovos (Boersma et al., 1990, Yorio e Boersma 1994). Depois estas viagens se tornam cada vez mais curtas, até o momento em que os parceiros trocam os deveres a cada dois dias, aproximadamente (Stokes e Boersma, 1999). Os ovos eclodem em meados de novembro e os filhotes são alimentados por ambos os pais por até 90 dias (Boersma et al., 1990, Boersma e Williams 1995, Stokes e Boersma, 1998).

Depois do período reprodutivo, os pinguins adultos passam pelo processo de troca de penas (período de muda), que dura aproximadamente dois meses (Boersma et al., 1990). A partir de abril, migram para outras localidades à procura de alimento, em direção ao norte utilizando a plataforma continental (Sick 1997, Putz et al., 2000, Putz et al., 2007). Durante a migração invernal é possível observar a chegada de pinguins à costa brasileira (Figura $1 \mathrm{~A}$ ), principalmente no litoral de Santa Catarina e do Rio Grande do Sul (Dantas et al., 2013).

Estima-se que existem entre 1.2 e 1.6 milhões de pares reprodutivos desta espécie, distribuídas em cerca de 138 colônias de tamanhos variáveis (Borboroglu e 
Boersma, 2013), podendo ser compostas de dezenas a milhares de indivíduos (Schiavini et al., 2005). Apesar do grande número de pares reprodutivos, atualmente esta é uma espécie classificada como 'Quase Ameaçada' pela União Internacional para a Conservação da Natureza (IUCN 2010) devido a estudos relatarem declínio populacional nas últimas décadas em várias de suas colônias, incluindo suas duas maiores (localizadas em Punta Tombo e Leones) (Boersma et al., 1990, Boersma 1997, Schiavini et a.l, 1995, Williams 1995).

\section{Análises de paternidade}

O uso de técnicas de biologia molecular para as análises de paternidade tiveram início com a descoberta do 'DNA fingerprinting' (Jeffreys et al., 1985) em que as variações em loci de minissatélites podiam ser visualizadas e usadas para identificar indivíduos e suas relações de parentesco. Entretanto, apesar de ser uma técnica metodologicamente simples, apresentava diversos tipos de limitações técnicas (visualização e identificação dos padrões de bandas) e estatísticas (determinação dos coeficientes de compartilhamento de bandas) e, por isso, foi só com a descoberta dos microssatélites (Tautz, 1989) que este tipo de análise ganhou maior importância (Jones et al., 2010). Os microssatélites foram os primeiros marcadores facilmente detectáveis, codominantes e altamente variáveis que foram desenvolvidos (Avise 2004; Pemberton 2009; Jones et al., 2010). Além disso, ao longo do tempo surgiram diversos métodos estatísticos e softwares distintos que complementam a biologia molecular para a realização das análises de paternidade. A utilização de tais métodos e softwares pode variar de acordo com o objeto de estudo, o tipo de marcador molecular usado, o número de indivíduos analisados e os tipos de erros que podem ocorrer nas análises.

O método de análise de paternidade mais simples é o de exclusão. Esta abordagem leva em conta o padrão de herança Mendeliana e o fato de que organismos diplóides que se reproduzem sexuadamente compartilham ao menos um alelo por locus com cada indivíduo de sua prole (Jones et al., 2010). Sendo assim, machos que possuem genótipos incompatíveis (que não compartilham algum alelo) 
com a prole em questão são rejeitados como pai, até que reste somente um macho no fim, sendo este então considerado geneticamente o verdadeiro pai.

Considerando-se uma população pequena, com poucos pais candidatos à paternidade e a utilização de marcadores altamente polimórficos, a análise por exclusão é possível (Freeland, 2005). Entretanto, geralmente não é este o panorama que encontramos nos estudos de paternidade, onde existe um grande número de pais candidatos e, muitas vezes, não são todos eles que podem ser amostrados. Além disso, problemas como erros de genotipagem, alelos nulos e mutações podem gerar falsas exclusões, ou então impossibilitar a exclusão de todos os indivíduos exceto um, deixando ao final da análise mais de um macho que pode ser considerado o verdadeiro pai (Marshall et al., 1998; Jones e Ardren, 2003).

Uma maneira de contornar estas limitações é utilizar métodos de atribuição de parentesco (ou atribuição categórica) em que é possível determinar, dentre todos os possíveis pais não excluídos, o macho com maior probabilidade de ser o verdadeiro pai da prole (Meagher, 1986; Jones e Ardren, 2003; Jones et al., 2010). Esta abordagem é baseada em cálculos do logaritmo de verossimilhança ( $L O D$ score), que é a razão da verossimilhança da probabilidade de um macho ser o pai da prole sobre a probabilidade de qualquer outro indivíduo ser o pai (Marshall et al., 1998), levando em conta tanto o grau esperado de compartilhamento de alelos entre os pais e os filhotes, quanto a frequência desses alelos dentro da população estudada. Além disso, este método é capaz de acomodar erros de genotipagem e considera que os loci estudados estão em equilíbrio de ligação (Marshall et al., 1998; Freeland, 2005, Kalinowski et al., 2007; Jones et al., 2010). O programa CERVUS 3.0 (Marshall et al., 1998), é um software que realiza este tipo de análise de paternidade e calcula os valores de LOD de cada possível pai. Existem três possibilidades de valores de LOD, e cada um significa uma determinada relação. Valores iguais a zero significam que o macho em questão tem igual probabilidade de um macho qualquer da população de ser o pai da prole. Quando o LOD é positivo significa que o possível pai tem maior probabilidade de ser o pai da prole do que outro macho aleatório da população e quando o LOD é negativo significa que ele tem menor probabilidade de ser o pai da prole do que um macho aleatório da população (casos em que os indivíduos compartilham muitos alelos). Se a 
paternidade de dois machos for igualmente possível, é provável que seus genótipos sejam idênticos, não sendo possível determinar a exclusão de algum deles.

Além disso, este programa é capaz de determinar a confiança estatística para cada paternidade atribuída através de simulações. Em cada atribuição realizada, um valor de logaritmo de variação ( $\boldsymbol{A}$ ) é calculado. Se apenas um macho apresentar valores positivos de LOD, o $\mathbf{\Delta}$ vai ser o próprio valor de LOD, mas se dois ou mais machos tiverem valores positivos, então o $\boldsymbol{\Delta}$ é a diferença entre os dois maiores valores de LOD obtidos. Esta abordagem serve para comparar a distribuição dos valores de para atribuições corretas e incorretas das simulações realizadas, com o objetivo de selecionar um valor crítico de $\boldsymbol{\Delta}$ que determine um nível de confiança desejado para as atribuições. Dessa forma, este valor crítico escolhido a partir das simulações é então usado para determinar a confiança na atribuição para a análise real do conjunto de dados empíricos do estudo. Assim, esta abordagem é capaz de indicar se o pai de cada prole foi atribuído com confiança ou não (Jones et al. 2010). A atribuição de paternidade ganha maior confiança quando incluídas informações sobre a maternidade dos indivíduos.

Existe um outro software, o ML RELATE, que também tem a função de avaliar as relações de parentesco entre os indivíduos através da análise de dados genéticos. Apesar de buscarem resultados semelhantes, estes programas apresentam metodologias distintas. De maneira geral, este programa considera que as relações genealógicas entre os indivíduos são representadas matematicamente como probabilidades de que os genótipos dos indivíduos podem compartilhar zero, um ou dois alelos idênticos por descendência (Lynch e Walsh, 1998; Buckleton et al., 2005). O ML RELATE é útil para discriminar entre quatro relações básicas de linhagens comuns: indivíduos não relacionados, meio irmãos, irmãos completos (mesmo pai e mesma mãe) e pais e filhos. Para isso, ele calcula estimativas de verossimilhança de parentesco ( $r$ ) para avaliar qual é o tipo de relação mais provável entre os indivíduos.

Assim como o CERVUS, o ML RELATE também leva em conta a possibilidade de erros de genotipagem, como a presença de alelos nulos. Com este software é possível analisar estas relações de parentesco de quatro maneiras diferentes: (1) através de uma matriz de parentesco par a par, em que são calculadas as probabilidades das quatro possíveis relações entre todos os indivíduos de uma população, com a relação 
de maior verossimilhança sendo considerada como verdadeira; (2) através de uma lista com os log de verossimilhança de todas as relações entre os pares de indivíduos; (3) através de uma lista com todas as possíveis relações de parentesco entre pares de indivíduos, determinados a partir de uma série simulações de genótipos randômicos gerando diferentes valores de confiança para cada relação; (4) através de testes de hipótese específicos entre indivíduos escolhidos pelo usuário, sendo necessário ter uma hipótese nula e uma alternativa para serem testadas (Kalinowski et al., 2006). Apesar do ML RELATE ser capaz de identificar diferentes relações de parentesco, não é possível incluir na análise informações de parentesco já conhecidas ou testadas previamente. O programa é capaz apenas de cruzar todos os dados genéticos e determinar o grau de parentesco entre os indivíduos, diferentemente do CERVUS. 


\section{Objetivos}

\section{Objetivo Geral}

Este trabalho visou estudar o comportamento reprodutivo dos Piguins-deMagalhães, através da avaliação da frequência de fertilização extra-par e identificação de possíveis fatores que poderiam influenciar esse acontecimento.

\section{Objetivos específicos}

(1) Determinar o sexo dos indivíduos coletados na Colônia reprodutiva da Ilha Quiroga;

(2) Estimar a razão sexual secundária de cada ninho amostrado;

(3) Verificar a paternidade dos adultos em relação aos filhotes de cada ninho amostrado;

(4) Estimar se há e qual a taxa de paternidade extra-par para os Pinguins-de-Magalhães nos indivíduos coletados da colônia da llha Quiroga nos anos de 2010 e 2011;

(5) Comparar a diversidade genética dos ninhos com e sem paternidade extra-par nos anos 2010 e 2011; e

(6) Relacionar as variáveis ambientais dos anos 2010 e 2011 com as frequências de paternidade extra-par. 


\title{
Artigo
}

\section{Molecular evidence of extra-pair paternity and intraspecific brood parasitism in Magellanic Penguin (Spheniscus magellanicus).}

\author{
Anna Carolina Milo Marasco, João Stenghel Morgante, Melina Barrionuevo, Esteban
}

Frere and Gisele Pires de Mendonça Dantas

Keywords: Magellanic penguins; Spheniscus magellanicus; Microsatellites, Extra-pair paternity; Monogamy; Intraspecific brood parasitism

\begin{abstract}
Recent studies have shown that, despite most of the avian species being socially monogamous, they present different reproductive strategies, such as extra-pair paternity (EPP) and intraspecific brood parasitism (IBP). We investigated the genetic mating system of Magellanic penguins (Spheniscus magellanicus), a seabird species that is supposed to be extremely monogamous, with low or no evidence of extra-pair paternity, due to philopatry, partners faithfulness among years and intense biparental care. During two breeding seasons (2010 and 2011) we sampled 170 individuals of 44 different nests from Quiroga Island colony (88 offspring, 38 putative mothers and 44 putative fathers) and the parentage was determined based on the analysis of 9 microsatellites markers. Extra-pair paternity was detected in $31 \%$ of all offspring and $48 \%$ of the nests had at least one extra-pair young. In addition, $6 \%$ of chicks were not the offspring of the putative mother or either member of the social pair, indicating evidence of intraspecific brood parasitism. These results reveals a low rate of IBP, but a high rate of EPP, both previously undescribed for this species and shows that Magellanic Penguins successfully engage in extra-pair copulations.
\end{abstract}




\section{Introduction}

Until a few decades ago, it was believed that great part of avian species presented monogamous sexual behavior (Lack, 1968). However, since the introduction of molecular markers to study avian mating systems, researchers have identified unexpected relationships between parents and offspring, revealing alternative reproductive strategies, such as extra-pair paternity (EPP) and intraspecific brood parasitism (IBP) (reviewed in Petrie and Moller, 1991; Birkhead and Moller, 1992; Petrie et al, 1998; Yom-tov, 2001).

Although $90 \%$ of bird species are socially monogamous, fewer than $20 \%$ of the studied species to date are genetically monogamous, as a result of females following mixed strategies by copulating with males other than their social partner (Griffith et al., 2002). High rates of EPP are associated with high rates of adult mortality and reduced parental care. Of all bird groups, passerines have shown the highest rates of extra-pair paternity, with some of the species exceeding $60 \%$ of offspring fathered by males different from the female's social pair (Emberiza schoeniclus Dixon et al., 1994; Turdus migratorius Montgomerie Briskie et al, 1997; Vireo olivaceus Morton et al., 1998; Malurus cyaneus Dunn and Cockburn, 1999). In contrast, seabirds have demonstrated low levels of extra-pair paternity (Birkhead and Moller, 1992, 1996; Quillfeldt et al., 2012), possibly due to intensive biparental care, indispensable for the survival of the offspring. However, by the year 2012, less than $10 \%$ of the nearly 450 species of seabirds were studied in relation to EPP (Quillfeldt et al., 2012). Among them, the highest rate was found in Larus ridibundus, which showed $33 \%$ of nests with at least one chick being the result of extra-pair copulation (Lezalová-Pialková, 2011).

Intraspecific brood parasitism (IBP) occurs when females lays eggs in the nests of other conspecific female and it has been observed in over 230 bird species (Yom Tov, 2001). Although EPP has been detected in most bird species, IBP is more common in precocial (reduced post-hatching parental care) than in altricial species and its high rates are associated with high fecundity (Sorenson, 1992; Yom-Tov, 2001; Arnold and Owens, 2002; Bennet and Owens, 2002). Moreover, it is believed that nesting in colonies could have an influence on high rates of IBP (Brown, 1984; Moller and 
Birkhead, 1993; Lyond and Everding, 1996; Brown and Brown, 2001; Brown and Lawes, 2007), as well as of EPP (Moller and Birkhead, 1993; Arnold and Owens, 2002).

The benefits of engaging in EPC for females are still much debated. Direct benefits of extra-pair copulation are assumed to be rare (Griffith et al., 2002) but it is believed that this behavior may have genetic (indirect) benefits. New genetic combinations generated by extra-pair paternity may contribute to the increased fitness of offspring (Jennions and Petrie, 2000; Zeh and Zeh, 2001). Thus, reproductive systems such as polyandry tend to result in offspring with greater genetic variability when compared to monogamous mates, increasing the fitness of offspring and providing evolutionary advantage to the species (Jennions and Petrie, 2000). Under this hypothesis, we expect extra-pair young to show greater genetic variability when compared to offspring of monogamous social partners.

Some studies have shown that extra-pair paternity may be related to skewed sex ratios for males. According to the sex allocation theory, females can produce offspring of the sex with greater fitness potential, manipulating sex ratio in order to maximize the reproductive success (Trivers and Willard, 1973; Charnov, 1982). Sex allocation in birds is not completely understood yet (Krackow, 1995) but there is evidence that sex ratio can be skewed in an adaptive manner in relation to several factors, including occurrence of extra-pair paternity (Svensson and Nilsson, 1996; Bradbury and Blakey, 1998; Kölliker et al., 1999; Whittingham and Dunn, 2000; Johnson et al., 2009). Males involved in extra-pair copulations are expected to be of higher quality in comparison to the female social partner. Therefore, a son has the potential to produce more offspring than a daughter does (Whittingham and Dunn, 2000; Leech et al., 2001;). Thus, we expect a sex ratio biased towards males in chicks fathered through extra-pair fertilizations.

Penguins (Spheniscidae) present intense biparental care, with couples sharing all parental duties almost equally, including incubation, since they must alternate in long foraging trips at sea (Williams, 1995). Therefore, it can be expected a strictly monogamous behavior with low levels of EPP and IBP, although, up to this moment, their sexual behavior from the genetic point of view was poorly studied. From the 18 species of penguins, only five of them had their sexual behavior genetically studied, using DNA fingerprinting. For Spheniscus humboldti, Eudyptes pachyrhynchos and 
Pygoscelis antarticus researchers found no genetic evidence of extra-pair paternity (Schwartz et al., 1999; McLean et al., 2000 Moreno et al., 2000). On the other hand, St. Clair et al. (1995) found that of 13 two-chick families of Eudyptes schlegeli only one individual was unrelated to its putative father (3.8\% of EPP) and Pilastro et al. (2001) found that the social father did not sire $10 \%$ of the 22 Pygoscelis adeliae offspring assessed. So far, these are the only proven cases of EPP in penguin species. Furthermore, no genetic evidence of IBP has been documented in any penguin species studied to date.

Magellanic penguins (Spheniscus magellanicus; Forster, 1781) occurs in the Pacific and Atlantic coasts of South America (Boersma and Williams, 1995; Simeone et al., 2003), and breed in colonies located in Argentina, Chile and Falkland Islands. These penguins breed during the period from September to April (Williams, 1995), lay a maximum of 2 eggs per brood and their nests are made under bushes or in burrows excavated in the ground (Frere et al., 1992; Stokes and Boersma, 1998). During their winter migration period in search for food, magellanic penguins can be occasionally seen at the Brazilian coast mainly in Santa Catarina and Rio Grande do Sul, but they can also be found as far north as Rio de Janeiro (Sick 1997, Stokes and Boersma, 1998). It is estimated that there are between 1.2 and 1.6 million of breeding pairs distributed in approximately 138 colonies (Schiavini et al., 2005; Borboroglu and Boersma, 2013). Despite the large number of individuals, this is a species currently classified as 'Near Threatened' by the International Union for Conservation of Nature (IUCN 2010) due to recent evidence of population decline in many of its colonies (Boersma et al., 1990, 1997; Boersma, and Schiavini et al. 1995, Williams, 1995).

This species does not display sexual dimorphism or seasonal variation and is philopatric (Boersma, 2008). Like other penguin species, it exhibits an intense biparental care, which suggests that the occurrence of extra-pair paternity and intraspecific brood parasitism is very low or nonexistent. Furthermore, Hood (1996) claims that, despite observing more than 500 copulations of this species at Punta Tombo colony (Argentina), none of them were characterized as extra-pair. Beyond that, there is no other work on assessing EPC or IBP in this species and no genetic study to assess paternity has been done to date. 
Within this context, the goals of this study were: (1) to evaluate the genetic mating strategy of the Magellanic penguins estimating the rate of EPP and IBP; (2) to evaluate if the incidence of extra-pair varies between years sampled; (3) in case of difference among years, to investigate if there is any correlation between environmental conditions, such as temperature and precipitation, in the rates of EPP; (4) to compare the genetic diversity among nests with and without occurrence of EPP and (5) to estimate the secondary sex ratio and compare the ratio between within and extra-pair offspring.

The genetic evaluation of the reproductive system of this species can certainly help to understand their genetic mating system, which is essential for a comprehensive insight in male and female reproductive behavior and for our understanding of the evolution of their social systems and individual reproductive strategies. 


\section{Materials and Methods}

\section{Study site and field work}

The study was conducted at Quiroga Island (Fig. 1), located at Puerto Deseado, Santa Cruz Province, Argentina $\left(47^{\circ} 45^{\prime} \mathrm{S}, 65^{\circ} 53^{\prime} \mathrm{W}\right)$ during two consecutive breeding seasons (from September to November of 2010 and 2011). This island is located inside the Deseado estuary, presents vegetation consisting mainly of bushes Suaeda divaricata and Atriplex sp (Cevasco et al., 2001) and hosts a colony of approximately 1,500 breeding pairs of Magellanic penguins ( $M$ Barrionuevo, personal communication).

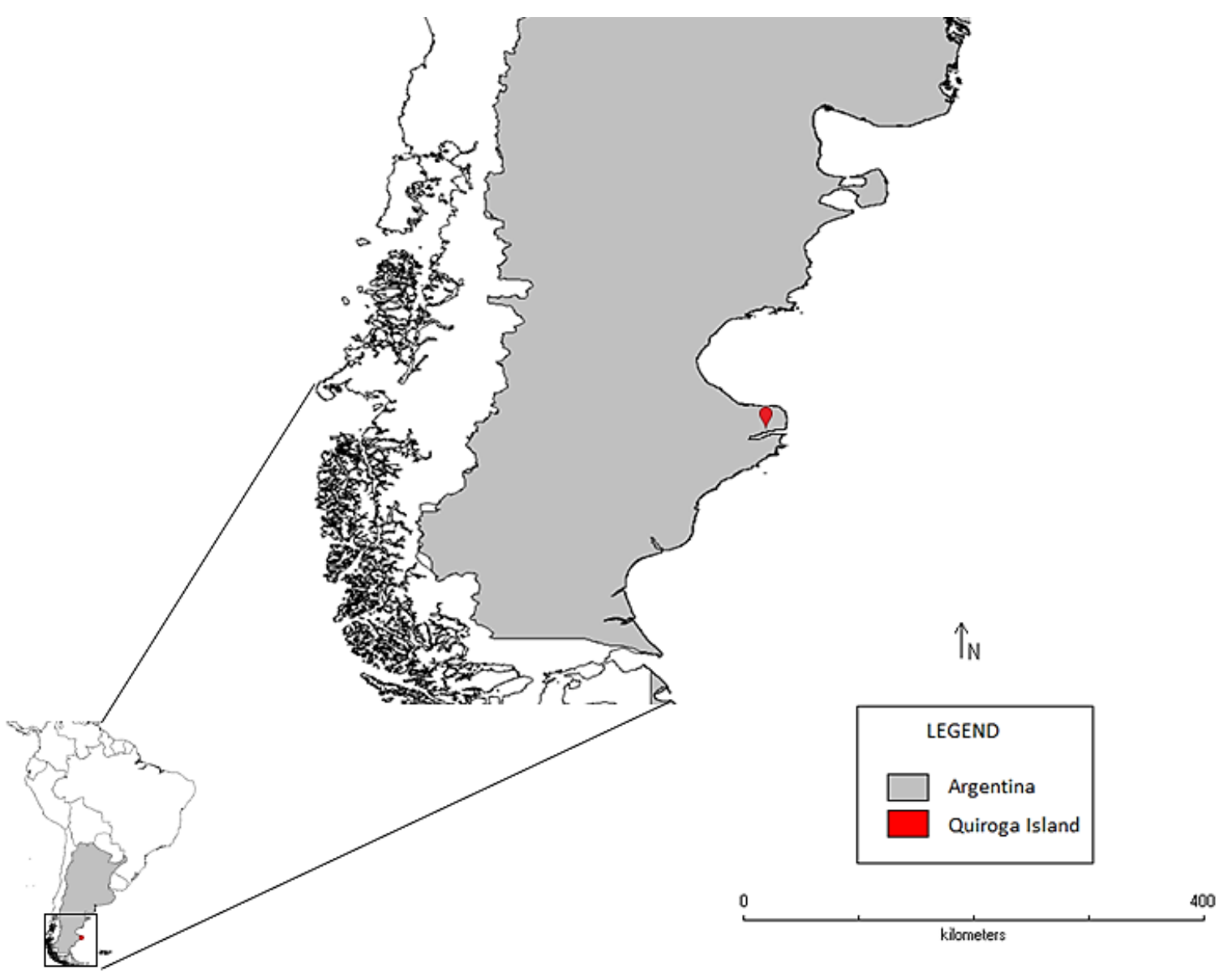

Fig. 1: Breeding colony of Magellanic Penguin at Quiroga Island 
After laying the second egg of the season, females were captured and banded on the fins with unique numbers. The sex was determined by cloaca inspection and later confirmed through molecular analysis (Griffiths et al., 1998). Males were caught and banded once they returned to the nests to begin their incubation period.

During the incubation period, all nests were verified every three days and we did not find any unidentified male or female at the nests, what made us believe that the adults captured in each nest were the real social pairs.

Blood samples were collected by puncturing the medial metatarsal vein of both chicks, males and females twenty days after the eggs have hatched and they were stored in $95 \%$ ethanol at $20^{\circ} \mathrm{C}$ until manipulation in laboratory. At total, we collected samples from 170 individuals (Table 1): 48 chicks and 42 adults (18 females and 24 males) from 24 nests in 2010, and 40 chicks and 40 adults (20 females and 20 males) from 20 nests in 2011.

Table 1. Number of individuals sampled in 2010 and 2011

\begin{tabular}{|c|c|c|c|c|}
\hline Year & No. Nests & No. Offspring & $\begin{array}{l}\text { No. putative } \\
\text { fathers }\end{array}$ & $\begin{array}{c}\text { No. putative } \\
\text { mothers }\end{array}$ \\
\hline 2010 & 24 & 48 & 24 & 18 \\
\hline 2011 & 20 & 40 & 20 & 20 \\
\hline TOTAL & 44 & 88 & 44 & 38 \\
\hline
\end{tabular}

\section{Molecular Methods}

\section{DNA extraction and Molecular Sexing}

Genomic DNA was extracted through standard phenol/chloroform technique after digestion with proteinase $\mathrm{K}$, precipitated with ethanol and resuspended in T.E. Buffer (Sambrook et al., 2001).

We used the molecular method described by Griffiths et al. (1998), with the primers P2 (5'-TCTGCAYCGCTAAATCCTTT-3') and P8 (5'-CTCCCAAGGATGAGRAAYTG-3') to sex all the individuals. PCR amplifications were prepared to the final volume of $10 \mathrm{ul}$, 
containing 10X PCR Sulfate Buffer (1M Tris, 10\% Tween, 1M Ammonium sulfate, $\mathrm{pH}$ 8.8), $2.0 \mathrm{mM}$ of $\mathrm{MgCl} 2,12 \mathrm{uM}$ of dNTPs, $10 \mathrm{pmol}$ of each primer, $0.5 \mathrm{U}$ of Taq Platinum DNA Polymerase (Invitrogen) and approximately $25 \mathrm{ng}$ of DNA.

The PCR cycling began with an initial denaturation of $94^{\circ} \mathrm{C}$ for 5 minutes, followed by 35 cycles of $94^{\circ} \mathrm{C}$ for 30 seconds, $51^{\circ} \mathrm{C}$ for 30 seconds, $72^{\circ} \mathrm{C}$ for 45 seconds, and ended with a final extension $72^{\circ} \mathrm{C}$ for 7 minutes. PCR products were separated by electrophoresis in 3\% agarose gels, visualized, and photographed under UV light. Males were identified by the presence of a single band $(360 \mathrm{pb})$ and females were identified by the presence of two bands (360pb and 380pb) (Bertellotti et al., 2002).

\section{Microsatellites amplification}

We used 15 microsatellites (Table 2 ) to assess the relationship between the individuals. Microsatellite primers were previously developed as described in Schlosser et al. $(2003,2009)$ and Akst et al. (2002). Although these molecular markers were originally developed for other penguin species, they were successfully cross-amplified and proved polymorphic in Magellanic penguins (Dantas et al., unpublished data)

PCR amplifications were prepared to the final volume of 10ul, containing $10 \mathrm{X}$ PCR Buffer (200mM Tris- $\mathrm{HCl}, 500 \mathrm{mM} \mathrm{KCl}$ - Promega), $2.5 \mathrm{mM}$ of $\mathrm{MgCl} 2,12 \mathrm{uM}$ of dNTPs, $5 \mathrm{pmol}$ of each primer, $0.5 \mathrm{U}$ of GoTaq Flexi Polymerase (Promega) and approximately 50ng of DNA. The PCR cycling began with an initial denaturation $94^{\circ} \mathrm{C}$ for 5 minutes, followed by 35 cycles $94^{\circ} \mathrm{C}$ for 30 seconds, annealing temperature (table 2) for 30 seconds, $72^{\circ} \mathrm{C}$ for 45 seconds, and ended with a final extension $72^{\circ} \mathrm{C}$ for 7 minutes. The PCR products obtained with fluorescently labelled primers, were genotyped in MegaBace 1000 sequencer (Applied Biosystems). 
Table 2. Summary of microsatellite loci used in this study, including their characteristics and literature sources

\begin{tabular}{|c|c|c|c|c|c|}
\hline Locus & $\begin{array}{l}\text { Repeat } \\
\text { Motive }\end{array}$ & Primer Sequence (5'-3') & $\begin{array}{l}\text { Dye } \\
\text { Label }\end{array}$ & Species & Reference \\
\hline Sh1Ca9 & $(\mathrm{GT})_{17}$ & $\begin{array}{c}\text { F:AGCAGATGTGGGGGTGTAG } \\
\text { R:AAGTCAGTGTTATGCCAAGATACG }\end{array}$ & HEX & $\begin{array}{l}\text { Spheniscus } \\
\text { humboldti }\end{array}$ & $\begin{array}{l}\text { Schlosser } \\
\text { et al. } 2003\end{array}$ \\
\hline Sh1Ca12 & $(A C)_{14}$ & $\begin{array}{c}\text { F:GCACACTGTGAGCTTGCAC } \\
\text { R:CTTGGGCTCTCAATACCC }\end{array}$ & FAM & $\begin{array}{l}\text { Spheniscus } \\
\text { humboldti }\end{array}$ & $\begin{array}{l}\text { Schlosser } \\
\text { et al. } 2003\end{array}$ \\
\hline Sh1Ca16 & $(C A)_{20}$ & $\begin{array}{c}\text { F:GTAGGGCAGCAGCACACC } \\
\text { R:TCTCCTGGAAAGCAGGAATCC }\end{array}$ & HEX & $\begin{array}{l}\text { Spheniscus } \\
\text { humboldti }\end{array}$ & $\begin{array}{l}\text { Schlosser } \\
\text { et al. } 2003\end{array}$ \\
\hline Sh1Ca17 & $(C A)_{15}$ & $\begin{array}{c}\text { F:GCCCTCAGTGGTTGCACA } \\
\text { R:GGTGGTCAAAACCCCTCTTT }\end{array}$ & FAM & $\begin{array}{l}\text { Spheniscus } \\
\text { humboldti }\end{array}$ & $\begin{array}{l}\text { Schlosser } \\
\text { et al. } 2003\end{array}$ \\
\hline Sh2Ca12 & $(C A)_{14}$ & $\begin{array}{l}\text { F:TCAGTGTACGAGCCAGAAGG } \\
\text { R:CTAGGATCCCGGCTTTTGTC }\end{array}$ & HEX & $\begin{array}{l}\text { Spheniscus } \\
\text { humboldti }\end{array}$ & $\begin{array}{l}\text { Schlosser } \\
\text { et al. } 2003\end{array}$ \\
\hline Sh2Ca21 & $(\mathrm{CA})_{11}$ & $\begin{array}{l}\text { F: AAATAAAGCCTATACACAACAGG } \\
\text { R:GTGCACTTAATGGGGTGTATG }\end{array}$ & FAM & $\begin{array}{l}\text { Spheniscus } \\
\text { humboldti }\end{array}$ & $\begin{array}{l}\text { Schlosser } \\
\text { et al. } 2003\end{array}$ \\
\hline Sh2Ca22 & $(\mathrm{CA})_{17}$ & $\begin{array}{c}\text { F:CAGCTGGCAGTGAGTCTGAG } \\
\text { R:GGACAGCTACCAGATAGAGTGC }\end{array}$ & HEX & $\begin{array}{l}\text { Spheniscus } \\
\text { humboldti }\end{array}$ & $\begin{array}{l}\text { Schlosser } \\
\text { et al. } 2003\end{array}$ \\
\hline $\operatorname{Sh} 2 C a 31$ & $(C A)_{14}$ & $\begin{array}{c}\text { F:ATCACAGCTCCCCCTTTCTC } \\
\text { R:AAGGCAAACAGAGTGGGATG }\end{array}$ & FAM & $\begin{array}{l}\text { Spheniscus } \\
\text { humboldti }\end{array}$ & $\begin{array}{l}\text { Schlosser } \\
\text { et al. } 2009\end{array}$ \\
\hline Sh2Ca40 & $(C A)_{18}$ & $\begin{array}{l}\text { F:AGCAGCACGCCCTCCCTC } \\
\text { R:TCTCCAGGAAGCAGGAATC }\end{array}$ & HEX & $\begin{array}{l}\text { Spheniscus } \\
\text { humboldti }\end{array}$ & $\begin{array}{l}\text { Schlosser } \\
\text { et al. } 2009\end{array}$ \\
\hline Sh2Ca49 & $(C A)_{20}$ & $\begin{array}{l}\text { F:GCTTTTCCACCAGCCTCTTCC } \\
\text { R:TTCTGTTCAAAGCGTGGTTG }\end{array}$ & FAM & $\begin{array}{l}\text { Spheniscus } \\
\text { humboldti }\end{array}$ & $\begin{array}{l}\text { Schlosser } \\
\text { et al. } 2009\end{array}$ \\
\hline Sh2Ca55 & $(C A)_{18}$ & $\begin{array}{l}\text { F:TGAGTCTGAGTGCTCAGTTGG } \\
\text { R:AGGGTCTGAAGGACAGCTACC }\end{array}$ & HEX & $\begin{array}{l}\text { Spheniscus } \\
\text { humboldti }\end{array}$ & $\begin{array}{l}\text { Schlosser } \\
\text { et al. } 2009\end{array}$ \\
\hline Sh2Ca58 & $(\mathrm{GT})_{10}$ & $\begin{array}{l}\text { F:TACAGCAATGCAGCGTGTGT } \\
\text { R:ACCTGGTAGAGGGCAGTAGT }\end{array}$ & FAM & $\begin{array}{l}\text { Spheniscus } \\
\text { humboldti }\end{array}$ & $\begin{array}{l}\text { Schlosser } \\
\text { et al. } 2009\end{array}$ \\
\hline B3-2 & $(\mathrm{GT})_{12}$ & $\begin{array}{l}\text { F:GGTGGTTATAGATGCACGAC } \\
\text { R:CAGTGCCCAGGAATCCAGTT }\end{array}$ & HEX & $\begin{array}{l}\text { Spheniscus } \\
\text { demersus }\end{array}$ & $\begin{array}{l}\text { Akst et al. } \\
2002\end{array}$ \\
\hline G3-6 & $(\mathrm{TG})_{10}$ & $\begin{array}{c}\text { F:TCTTAAGGTCTTGCACAC } \\
\text { R:GAGCTCAGTAACTGCAGGCA }\end{array}$ & HEX & $\begin{array}{l}\text { Spheniscus } \\
\text { mendiculus }\end{array}$ & $\begin{array}{l}\text { Akst et al. } \\
\quad 2002\end{array}$ \\
\hline G2-2 & $(\mathrm{GT})_{13}$ & $\begin{array}{c}\text { F:ATGACATATTGATTGGC } \\
\text { R:CTGCCTGAACTAAGCTTTGTC }\end{array}$ & FAM & $\begin{array}{l}\text { Spheniscus } \\
\text { mendiculus }\end{array}$ & $\begin{array}{l}\text { Akst et al. } \\
2002\end{array}$ \\
\hline
\end{tabular}


We used Fragment Profiler Software (MEGABACE 1000, Applied Biosystems) to visualize and characterize all genotypes. We repeated PCR amplifications and genotypic analysis at least three times for each sample.

\section{Paternity estimations}

\section{Data analyses}

Paternity was determined using likelihood-based approach in CERVUS 3.0 (Marshall et al., 1998), taking into account allele frequencies in the population, the number of possible candidate parents, the proportion of candidate parents sampled, and the percentage of missing genetic data and genotyping errors. In this software we made four different analyses: allele frequency, simulation of paternity analysis, maternity tests and paternity tests.

First, we calculated the frequency of each allele for each locus within the population. These analyses included tests for Hardy-Weinberg equilibrium and presence of null alleles. Then, we made simulations of paternity analysis to examine the feasibility of parentage analysis with this set of loci. This step is important for the real analysis because it enable the determination of the confidence of each parentage assignments (Marshall et al., 1998). Afterwards, we checked the maternity for each nest, to check for egg dumping (when the social mother does not correspond to the genetic mother). After we checked, paternity was assigned for all offspring, using the social mother as "known parent". When the sample of the adult female was not available, we only tested the paternity.

We compared the rates of extra-pair paternity between the two breeding seasons, to verify if there was difference in the mean incidence of infidelity among these two years. Furthermore, we evaluated if the difference in the incidence of extrapair paternity could be related to environmental variables such as temperature and precipitation. Weather data was retrieved from the Puerto Deseado Aerodrome, Argentina, approximately 10 kilometers from our study site, and we calculated the average temperature and precipitation of each month of the breeding season (September, October and November). We used two-tailed unpaired t-test (considering 
two independent groups) to evaluate if there was significant difference between these means.

We also used t-test to compare the mean genetic diversity among extra-pair young and within-pair young, to check if there was any heterozygosity difference.

\section{Results}

\section{Allele frequencies}

From the initial set of 15 loci, we used only nine to conduct the parentage analysis (Table 3). Two were excluded due to problems in the amplification and difficulties in the genotypic analysis (Sh2Ca12 and Sh1Ca17). Two other loci (Sh2Ca58 and Sh1Ca12) were excluded because they exhibited high values of null alleles and deviated significantly from the Hardy-Weinberg equilibrium even after Bonferroni correction, thus affecting the parentage analysis. Although the loci Sh2Ca31, Sh2Ca21 and Sh2Ca22 showed some evidence of null alleles (being the highest frequency of null allele 0,08 ) they should not affect the parentage analysis greatly (Dakin and Avise, 2004), so they were maintained. From the remaining 11 loci, two had more than $5 \%$ of missing data (G3-6 and G2-2) and were also excluded.

This final set of nine loci showed sufficient levels of polymorphism, making them suitable for paternity assessment in this species. The mean number of alleles per locus was 10.1 with an average observed heterozygosity of 0.75 . The combined nonexclusion probability of all loci for first parent was 0,01 and for second parent 0,0004 . Values of polymorphism and non-exclusion probabilities for each locus are presented in Table 3. 
Table 3. Characteristics of the nine microsatellite used in the parentage analysis and the two loci excluded due to presence of null alleles.

$\mathbf{N}$, Number of samples that amplified successfully; Ho, observed heterozygosity; He, expected heterozygosity; F(Null), estimated frequency of the null allele; NE-1P, non-exclusion probability for the first parent; NE-2P, non-exclusion probability for the second parent

\begin{tabular}{c|ccccccccccc} 
Locus & $\boldsymbol{N}$ & $\begin{array}{c}\text { Annealing } \\
\text { temperature }\end{array}$ & $\begin{array}{c}\text { Size Range } \\
(\mathbf{b p})\end{array}$ & $\begin{array}{c}\text { No. of } \\
\text { Alleles }\end{array}$ & Ho & He & HWE & X2 $\boldsymbol{p}$ value & $\boldsymbol{F}($ Null) & NE-1P & NE-2P \\
\hline Sh2Ca49 & 162 & 56 & $101-114$ & 7 & 0,686 & 0,730 & NS & 0,781 & 0,026 & 0,686 & 0,513 \\
Sh2Ca55 & 165 & 56 & $86-116$ & 8 & 0,691 & 0,726 & NS & 0,282 & 0,017 & 0,682 & 0,505 \\
Sh1Ca9 & 166 & $60-61$ & $111-131$ & 9 & 0,747 & 0,828 & NS & 0,827 & 0,048 & 0,519 & 0,345 \\
Sh2Ca31 & 167 & 56 & $97-125$ & 12 & 0,623 & 0,741 & $*$ & 0,003 & 0,081 & 0,654 & 0,476 \\
Sh2Ca21 & 163 & 60 & $93-123$ & 11 & 0,748 & 0,831 & $*$ & 0,005 & 0,045 & 0,515 & 0,343 \\
Sh1Ca16 & 165 & 62 & $78-120$ & 12 & 0,752 & 0,828 & NS & 0,137 & 0,047 & 0,509 & 0,337 \\
Sh2Ca22 & 147 & $56-58$ & $84-142$ & 10 & 0,660 & 0,745 & $*$ & 0,001 & 0,058 & 0,655 & 0,475 \\
Sh2Ca40 & 163 & $60-61$ & $72-102$ & 13 & 0,810 & 0,842 & NS & 0,329 & 0,017 & 0,482 & 0,314 \\
B3-2 & 145 & 58 & $297-302$ & 11 & 0,531 & 0,626 & NS & 0,037 & 0,091 & 0,777 & 0,612 \\
Sh2Ca58 & 162 & $56-57$ & $96-110$ & 8 & 0,297 & 0,633 & $* * *$ & $1,30 \mathrm{E}-24$ & $\mathbf{0 , 3 7 1}$ & -
\end{tabular}




\section{Molecular sexing}

We determined the sex of 148 of 170 samples. Although sexing was successful for most of the samples, we were unable to determine the sex of 22 individuals due to lack of enough DNA to perform all analyses. These individuals were excluded from the sex ratio analysis.

However, for kinship analysis, we considered the sex determined through cloaca inspection for the adults (putative mother and father) that did not have their sex confirmed through molecular analysis.

\section{Parentage Analysis}

Offspring with a minimum of two mismatching loci were considered nondescendant from their social parent: when an offspring did not match the putative father it was considered to be extra-pair young (EPY) and when an offspring did not match the putative mother or both of the putative parents, it was considered to be a case of intraspecific brood parasitism. Mismatches at only one loci were considered as resulting from mutation or null alleles.

\section{Maternity analysis}

Maternity was assigned to the putative mother in $94 \%$ of the cases. In $2010,2 \%$ of the offspring did not match the social mother $(n=1)$. In 2011 , we found $10 \%$ of mismatched maternity $(n=4)$. Another four offspring were not assigned to the social mother, but since there was a lot of missing data for these females (at least 4 loci) we considered these cases as being a result of genotyping error.

Therefore, we found that $6 \%$ of the offspring ( $n=5$ from 88 offspring) were not assigned to the social female, likely representing a case of intraspecific brood parasitism. The level of support for this result was high, because there was at least 3 mismatches between the offspring and the maternal genotype. 


\section{Paternity analysis}

We found that $31 \%$ of the offspring ( $n=27$ of 88 ) were assigned to a male different from the social father, and $48 \%$ of the nests ( $n=21$ of 44 ) had at least one offspring considered as an extra-pair young. From the 21 nests with confirmed EPP, six contained two extra-pair offspring (three from each year sampled), and the 15 remaining had only one extra-pair offspring.

In 2010, $29 \%$ of the offspring were considered sired by an extra-pair male ( $n=14 ; 42 \%$ of the nests) and in 2011, 32\% ( $n=13 ; 55 \%$ of the nests). We found a slightly difference in the incidence of extra-pair paternity between this two breeding seasons.

When comparing the means of temperature and precipitation between the two breeding seasons, we found significant differences in the temperature of September and November (table 4), with 2011 having higher temperatures than 2010. However, there was no significant difference among the years in relation to the pluviosity (table 5).

Table 4. Mean temperature and $p$ value of the T-test for each month analyzed of 2010 and 2011. Values in bold were significantly different

\begin{tabular}{c|ccc} 
& Sept & Oct & Nov \\
\hline 2010 Mean Temperature $\left(C^{\circ}\right)$ & 4 & 11 & 12 \\
2011 MeanTemperature $\left(C^{\circ}\right)$ & 7 & 11 & 16 \\
T test $(p$ value) & $\mathbf{0 , 0 0 5}$ & 0,93 & $\mathbf{0 , 0 0 0 8}$
\end{tabular}

Table 5. Mean precipitation and $p$ value of T-test for each month analyzed of 2010 and 2011

\begin{tabular}{c|ccc} 
& Sept & Oct & Nov \\
\hline 2010 Mean Precipitation $(\mathrm{mm})$ & 0,0 & 0,42 & 0,01 \\
2011 Mean Precipitation $(\mathrm{mm})$ & 0,90 & 0,67 & 0,05 \\
T test ( $p$ value) & 0,1 & 0,69 & 0,19
\end{tabular}


Furthermore, when we compared the genetic diversity between within and extra-pair offspring (fig.2), we found no significant difference ( $t=2,3 ; p=0,82)$.

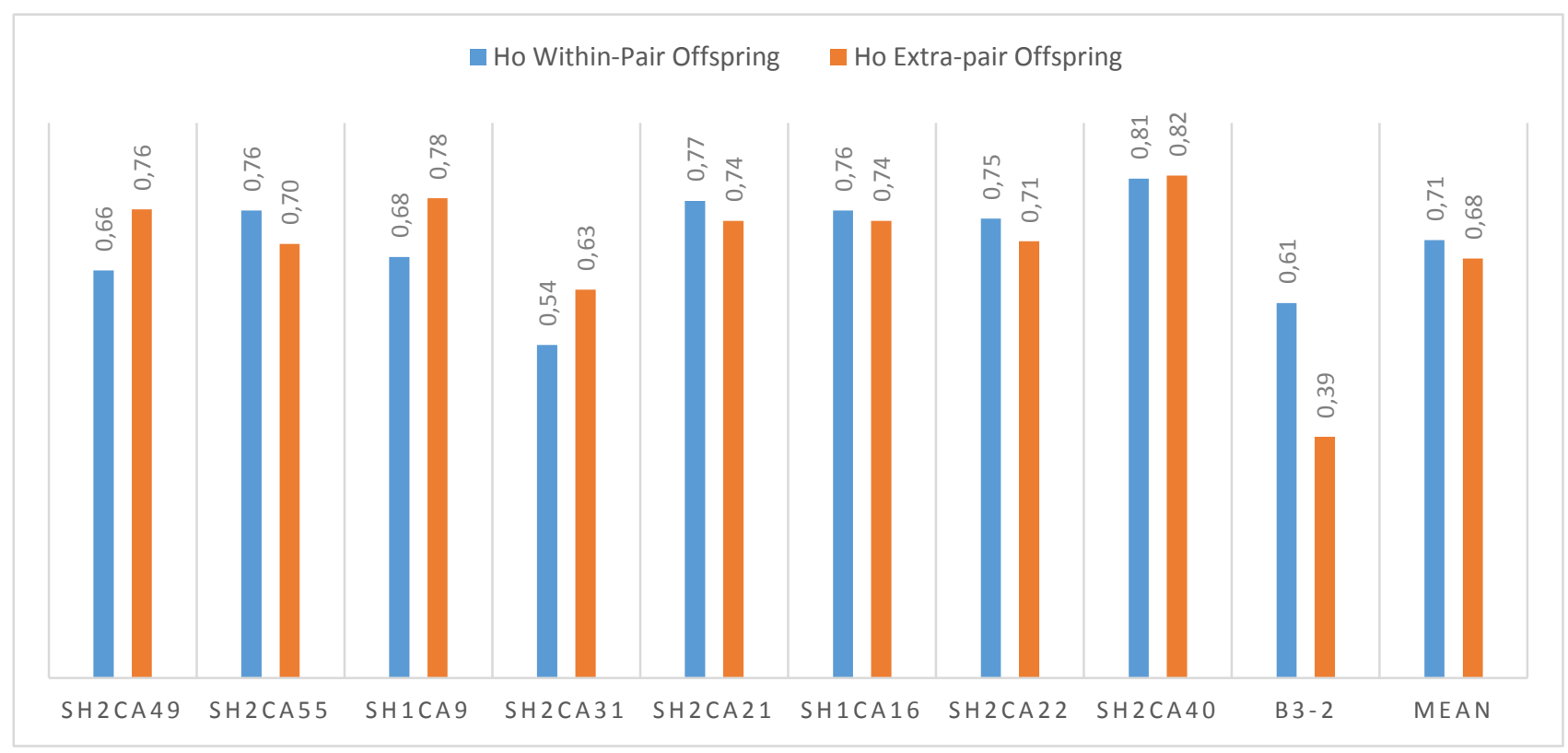

Fig. 2 Observed heterozygosity for each locus and mean observed heterozygosity of within and extra-pair offspring

\section{Sex Ratio}

Overall, the population showed no sex bias for quaternary sex-ratio among nests. From 148 individuals that were sexed we identified 78 males (53\%) and 70 females (47\%) ( $\chi 2$ =0,43; d.f. $=1 ; p=0,5$ not significant).

The same pattern was observed when we determined the sex of all offspring and calculated the sex ratio of within and extra-pair nestlings. Among the 55 offspring sired by the social father, $44 \%(\mathrm{~N}=24)$ were male and the remaining $56 \%$ were female $(\mathrm{N}=31)$, whereas among 21 extra-pair offspring $67 \%(\mathrm{~N}=14)$ were male and $33 \%(\mathrm{~N}=7)$ were female. The frequency of male and female offspring did not show a significant variation in sex ratio according to the female social partner $(\chi$ $2=0,9 ;$ d.f. $=1 ; p=0,34$ not significant $)$ or to extra-pair male that sired them $(\chi 2=$ 2,$3 ;$ d.f. $=1 ; p=0,12$ not significant). 


\section{Discussion}

\section{Frequency of extra-pair paternity and brood parasitism}

Our results showed that Magellanic penguins are not strictly monogamous in their mating behavior as previously thought (31\% of EPP and $48 \%$ of nests). Although no cases of extra-pair copulation have been reported for this species (Borboroglu and Boersma, 2013), it is well known that behavioral observations alone may not be the best way of measuring an individual's reproductive success (Westneat, 1987; Wink e Dyrcz, 1999; Griffiths et al., 2002).

The EPP rate found in our study is considered high when compared to other seabirds (e.g. Mauck et al. 1995; Gilbert et al. 1998; Lorentsen et al. 2000; Griggio et al. 2004), including other penguin species. Among the five penguin species that had their sexual behavior genetically investigated (Spheniscus humboldti, Schwartz et al. 1999; Eudyptes schlegeli, St Clair et al. 1995; Eudyptes pachyrhynchos, McLean et al. 2000; Pygoscelis antarticus, Moreno et al, 2000; Pygoscelis adeliae, Pilastro et al. 2001), only two of them showed evidence of EPP: Eudyptes schlegeli (Royal Penguin), with $3.8 \%$ of EPP ( $n=13$ nests, St Clair et al. 1995) and Pygoscelis adeliae (Adélie Penguin) , with $9.1 \%$ of EPP ( $n=18$ nests, Pilastro et al. 2001). However, all of these studies used DNA fingerprinting to assess the paternity of the offspring. This technique has some limitations such as visualization and calculation of band sharing which may have underestimated extra-pair paternity rates in those cases (Webster and Westneat, 1998). Microsatellite overcame other methods for assessing kinship, due to its random distribution across the genome, selective neutrality and high level of polymorphism that provides highly accurate exclusion of identity and paternity (Webster and Reichert, 2005; Jones et al. 2010).

High EPP rates could be explained by several behavioral and environmental factors. Magellanic penguin shows breeding synchrony and variable breeding densities that changes from colony to colony and these factors have been suggested to affect variation in EPP in avian mating systems (Møller and Birkhead 1993; Stutchbury and Morton 1995; Westneat and Sherman 1997; Weatherhead and Yezerinac 1998). 
According to the density hypothesis, the increased proximity among individuals influence mating opportunities when searching for potential extra-pair mates, thereby reducing the costs of extra-pair copulations (Westneat et al. 1990; Westneat and Sherman, 1997; Mayer and Pasinelli, 2012). It is possible that in the colony from Quiroga Island, the proximity of nests is high enough so that the energetic costs for searching for extra-pair mates are low. Moreover, since the within-pair and extra-pair copulations occur in the area around their territories, it is possible to relate the density with extra-pair copulation opportunities (Bouwman and Komdeur, 2006; Mayer and Pasinelli, 2012). However, it is important to do a comparative study between colonies of different densities to evaluate how this factor can really influence the sexual behavior of this species.

The relationship between breeding synchrony and EPP among species has been strongly debated (Weatherhead and Yezerinac, 1998; Griffith et al, 2002; Spottiswoode and Moller, 2004). Magellanic penguins breed once a year, and all adults are fertile during the same period (Borboroglu and Boersma, 2013). The breeding synchrony hypothesis suggests that there is a positive relationship between synchronous breeding and extra-pair copulation (Stutchbury and Morton, 1995). Greater synchrony allows females to assess male quality more accurately by comparing displaying males and it could also enhances opportunities of extra-pair mating for males. Thus, in this case, females initiate and control extra-pair copulations (Thusius et al. 2001).

Another reason that may explain the high rate of extra-pair paternity we found in our study is mate switching behavior. Some of the mismatching paternity could be the result of female switching mates during the pre-laying period (before pairing with their actually pair mate). This type of behavior has been reported in two penguin species: Adélie penguin (15\% of females had temporary partners; Hunter et al., 1995) and King penguins (34\% of females and $42 \%$ of males switched partners at least once; Olsson et al., 2001). There is the possibility that the six nests of Magellanic penguins in which all two chicks were found to be sired by a male other than the social father could be cases of mate switching, while the others are truly due to extra-pair copulations. Since we do not have any behavioral data that confirms mate switching in this species, we could not differentiate the paternities 
that were a result of extra-pair copulations or mate switching behavior. Therefore, all cases of mismatching paternity were defined as being a result of successful extrapair copulations. However, we believe that further studies are necessary to better understand the high incidence of mismatching paternity in this species.

Since this work does not include observation of mating behavior, it is not possible to infer about the direct benefits that extra-pair copulation can provide for this species. Males of Magellanic penguins clearly benefits from engaging in extrapair copulations, increasing the number of offspring through the generations (Wink and Dyrcz, 1999), but the reasons for females to do so remain poorly understood (Griffiths et al., 2002). We did not detect the expected higher genetic diversity among extra-pair offspring. Therefore we cannot assume that there is a genetic benefit for the offspring or the female that engaged in extra-pair copulations. Possibly females are able to increase the genetic quality and fitness of their offspring ("good gene" hypothesis) when engaging in extra-pair copulations with males of higher genetic quality than their social partner (Westneat et al., 1990; Birkhead and Møller 1992; Petrie and Kempenaers, 1998; Griffith et al., 2002). These good genes may be linked, for example, with the generation of larger extra pair offspring (Dreiss et al., 2008), better immune system (Arct et al., 2013) or higher reproductive capacity (Tschirren et al., 2012). Therefore, it is necessary more data about the offspring characteristics to test this hypothesis.

Besides cases of EPP, we found genetic evidence of intraspecific brood parasitism (6\% of offspring), previously undescribed in this species. IBP has already been reported in seabirds, (eg. Yom Tov, 2001; Duda et al., 2008; Lezalová-Piálková, 2011) but was not investigated in any penguin species. Given that Magellanic penguins presents intense biparental care, our findings of low rate of IBP supports the notion that IBP rates are lower in altricial species than in precocial ones (YomTov, 2001). On the other hand, this result may be related to the fact that Magellanic penguins breed in colonies and IBP is more likely to happen than in solitary nesters (Brown and Brown, 2001). It is also possible that there is a lack of territorial defense, which leads to higher opportunities for IBP (Brown, 1984). 


\section{Variation of Extra-pair paternity among years}

The EPP rates in 2010 were slightly lower than in 2011 and there was significant difference in the mean temperature in two of three months we analyzed among the years.

Local environmental factors, such as variation in temperature and precipitation, can affect breeding parameters (Hoset et al., 2004) and the costs and benefits of extra-pair mating behaviour (Birkhead and Møller, 1992), influencing the rates of extra-pair paternity (Johnsen and Lifjeld, 2003; Bowman and Komdeur, 2006). Extreme weather conditions may act as constraints on extra-pair mating behavior through influencing energy expenditure or food availability (Westneat 1994, Dawson and O'Connor, 1996; Vaclav et al., 2003; Hoset et al., 2013).

Global climate variations can cause changes in ocean productivity and, consequently, affect the foraging behavior of penguins (Borboroglu and Boersma, 2013). In the last few decades, it was observed that the Magellanic penguins had to travel greater distances to feed (Boersma, 2008) and, as this distance increases, the reproductive success decreased (Boersma and Rebstock, 2009). Thus, the climatic differences between years can cause changes in the ability of penguins to engage in extra-pair copulations. Probably in years with lower availability of food, penguins must expend more energy to travel and forage, so the ability to search for extra-pair partners decreases.

However, we did not find any relation of the rate of EPP and climate variation among years. Magellanic penguin from Argentina coast prey especially argentine anchovy (Borboroglu and Boersma, 2013) and this species tend to decrease during periods of increasing temperature (Ciechomski and Vigo, 1971). Because 2011 was a warmer year, with higher mean temperature, we would expect to find lower rates of EPP, since higher temperatures decreases the food availability and should influence in their foraging behavior. Furthermore, there was no significant difference in the pluviosity, so this could not have any relation in the variation of EPP among these breeding seasons. Therefore, it is possible that the weather did not vary enough to influence in the foraging behavior and, consequently, the extra-pair paternity rate. In addition, we found an overall high rate of infidelity so the climatic conditions were not a constraint to the extra-pair behavior. 


\section{Extra-pair paternity and sex ratio}

Although in our study the number of extra-pair sons was slightly higher than the number of daughters, they did not differ significantly and we could not find any bias towards males. This implies that Magellanic penguins females in our study were not assigning individual chicks to a particular sex on the basis of paternity.

According to the sex allocation theory, it is expected that when females copulates with males of higher quality they tend to produce more male offspring, which suggests that females are able to bias sex ratio towards the sex with higher reproductive value (Trivers and Willard 1973; Charnov, 1982; Leech et al., 2001). However, recent studies that evaluated the sex ratio of birds have shown conflicting results. Many of them have found no evidence for consistent brood sex ratio skews (Saino et al., 1999; Westerdahl et al., 1997; Radford and Blakey, 2000), while others have found significant correlations between brood sex ratio, various indicator of male quality, adult physical conditions and occurrence of extra-pair paternity (Kempenaers et al., 1997; Johnson et al., 2009).

It is possible that females of this species are not able to directly influence the paternity of specific ova (Vetter et al., 2013), or that we could not detect the real bias. Johnson et al. (2009) suggests that small sample sizes may limit the ability to detect small but potentially meaningful biases in offspring sex ratios. Since we were not able to sex all the samples we have collected this may have influenced our results. 


\section{Conclusion}

We found genetic evidence that even though no extra-pair copulations were observed in previously studies of Magellanic penguins mating behavior, they present high rates of extra-pair paternity, showing that a molecular approach is essential for determining the real mating system of the species. However, it is necessary to expand the study of reproductive behavior of this species to compare variations between populations, and to assess which ecological and climatic factors can influence in this behavior. Moreover, observational data must complement the genetic data to evaluate possible direct benefits of this behavior. Male, female and offspring physical conditions and characteristics may also be a good parameter to evaluate the benefits of engaging in extra-pair copulations.We also found genetic evidence of low rates of intraspecific brood parasitism, which is expected for species with such an intense biparental care as magellanic penguins. 


\section{Resumo}

Apesar de a monogamia social ser dominante entre as aves, análises genéticas revelaram relações de parentesco inesperadas, evidenciando diferentes estratégias de reprodução, como a paternidade extra-par e o parasitismo de ninho. Espécies de passeriformes estão entre as mais promíscuas, com altas taxas de paternidade extra-par, enquanto em aves marinhas esse comportamento demonstrou ser menos frequente.

Pinguins (Família Spheniscidae) compõem um grupo de 18 espécies de aves marinhas pelágicas e que tem em comum a filopatria, fidelidade a um parceiro e intenso cuidado biparental. Portanto, espera-se que apresentem um comportamento estritamente monogâmico e taxas de paternidade extra-par insignificantes.

Avaliamos pela primeira vez o sistema reprodutivo dos Pinguins-deMagalhães através de uma abordagem genética, buscando investigar a existência e frequência de paternidade extra-par e parasitismo de ninho. O parentesco de 88 filhotes de 44 ninhos de uma colônia na llha Quiroga (Argentina) foi determinado com base em análises de 9 marcadores microssatélites.

Encontramos baixas taxas de parasitismo de ninho (6\%), mas altas taxas de paternidade extra-par (31\% e 48\% dos ninhos com pelo menos 1 filhote extra-par). Entre os dois anos coletados, encontramos uma pequena diferença na incidência de infidelidade (29\% em 2010; 32\% em 2011), mas não houve relação com as condições climáticas do período de reprodução da espécie. Além disso, apesar da alta taxa de filhotes extra-par, não encontramos diferença significativa na diversidade genética e nem viés da razão sexual secundária.

Acreditamos que a alta taxa de paternidade extra-par encontrada possa ter relação com o comportamento reprodutivo em colônia, a densidade populacional, o sincronismo reprodutivo, ou que parte da paternidade que não correspondeu aos pais sociais seja resultado de troca de parceiros antes da definição final dos casais em cada estação reprodutiva. 
Nosso estudo pode ajudar a melhor entender e caracterizar o sistema reprodutivo dos Pinguins-de-Magalhães e indica que a espécie é socialmente, mas não geneticamente monogâmica.

Palavras chave: Pinguins de Magalhães; Spheniscus magellanicus; Microssatélites; Paternidade Extra-par, Monogamia 


\section{Abstract}

Despite the social monogamy being dominant among birds, genetic analysis revealed unexpected kinship relations, showing different reproductive strategies, such as extra-pair paternity and brood parasitism. Passerine species are among the most promiscuous, with high extra-pair paternity rates, while in seabirds this behavior is typically rather less frequent.

Penguins (Spheniscidae Family) are a group of 18 species of pelagic seabirds that have in common philopatric behavior, faithfulness to one partner and intense biparental care. Therefore, they are expected to have a strictly monogamous behavior and insignificant rates of extra-pair paternity.

For the first time, we evaluated the reproductive system of Magellanic Penguins (Spheniscus magellanicus) through genetic analysis in order to investigate the existence and frequency of extra-pair paternity and brood parasitism. The kinship of 88 offspring of 44 nests from a colony on Quiroga Island (Argentina) was determined based on the analyses of 9 microsatellite markers.

We found low rates of brood parasitism (6\%), but high extra-pair paternity rates ( $31 \%$ and $48 \%$ of nests with at least one extra-pair offspring). Between the two years sampled, we found a small difference in the incidence of infidelity ( $29 \%$ in 2010; 32\% in 2011), but no connection with the climatic conditions of each breeding season. In addition, despite the high rate of extra-pair offspring, we found no significant difference in the genetic diversity and no bias in the secondary sex ratio.

We believe that the high rate of extra-pair paternity found in our study may be a result of their reproductive behavior of nesting in colonies, breeding synchrony, density, or that part of the mismatching paternity is due mate switching.

Our study may help to better understand and characterize the reproductive system of Magellanic penguins and indicates that this species is socially but not sexually monogamous.

Palavras chave: Magellanic Penguins; Spheniscus magellanicus; Microsatellites; Extra-pair paternity, Monogamy 


\section{Referências Bibliográficas}

Akst, E.P., Boersma, P.D., Fleischer, R.C., 2002. A comparison of genetic diversity between the Galápagos penguin and the Magellanic penguin. Conservation Genetics, 3: 375-383.

Arct A, Drobniak SM, Podmokła E, Gustafson L, Cichoń M, 2013. Benefits of extra-pair mating may depend on environmental conditions: an experimental study in the blue tit (Cyanistes caeruleus). Behav. Ecol. Sociobiol, 67: 1809-1815.

Arnold KE, Owens IPF, 2002. Extra-pair paternity and egg dumping in birds: life history, parental care and the risk of retaliation. Proceedings of Biological Sciences, The Royal Society, 269(1497): 1263-9.

Austin JJ, Parkin DT, 1996. Low frequency of extra-pair paternity in two colonies of the socially monogamous short-tailed shearwater Puffinus tenuirostris. Molecular Ecology, 5:145-150

Avise JC, 2004. Molecular Markers, Natural History, and Evolution. Sinauer, Sunderland: Springler US.

Barash DP, 1976. Male response to apparent female adultery in the Mountain Bluebird (Sialia currucoides): an evolutionary interpretation. American Naturalist, 110:1097-1101.

Bennett PM, Owens IPF, 2002. Evolutionary ecology of birds: life histories, mating systems and extinction. Oxford University Press.

Bertellotti M, Tella JL, Godoy JA, Blanco G, Forero MG, Donázar JA, Ceballos O, 2002. Determining Sex of Magellanic Penguins Using Molecular Procedures and Discriminant Functions. Waterbirds, 25: 479-484.

Birkhead TR, Møller AP. 1992. Sperm Competition in Birds. New York: Academic Press.

Birkhead TR, Møller AP, 1996. Monogamy and sperm competition in birds. In: Black, JM eds. Partnerships in Birds: the Study of Monogamy. Oxford: Oxford University Press. p. 323-343.

Bjørnstad G, Lifjeld JT, 1997. High frequency of extra-pair paternity in a dense and synchronous population of Willow warblers Phylloscopus trochilus. Journal of Avian Biology, 28:319-324. 
Blomqvist D, Andersson M, Küpper C, Cuthill IC, Kis J, Lanctot RB, Sandercock BK, Székely T, Wallander J, Kempenaers B, 2002. Genetic similarity between mates and extra-pair parentage in three species of shorebirds. Nature, 419:613-615.

Boersma PD, 1997. Magellanic Penguin decline in the South Atlantic. Penguin Cons. 10:2-5

Boersma PD, 2008. Penguins as marine sentinels. Bio- Science, 58: 597-607.

Boersma PD, Stokes DL, Yorio PM, 1990. Reproductive variability and historical change of Magellanic penguins (Spheniscus magellanicus) at Punta Tombo, Argentina. In: Davis LS, Darby JT, editors. Penguin biology. San Diego: Academic Press. p. 15-43

Boersma PD, Rebstock GA, 2009. Foraging distance affects reproductive success in Magellanic penguins. Mar. Eco. Pro. 375: 263-275.

Borboroglu P, Boersma PD (Eds.), 2013. Penguins: Natural History and Conservation. Seattle: University of Washington Press.

Bowman KM and Komdeur J, 2006. Weather conditions affect levels of extra-pair paternity in the reed bunting Emberiza schoeniclu. Journal of Avian Biology 37(3): 238-244.

Bradbury RB, Blakey JK, 1998 Diet, maternal condition, and offspring sex ratio in the zebra finch, Poephila guttata. Proc. R. Soc. Lond. B 265, 895-899.

Briskie J, Montgomerie R, 1997. Sexual selection and the intromittent organ of birds. Journal of Avian Biology, 28:73-86.

Brown CR, 1984. Laying eggs in a neighbor's nest: benefits and costs of colonial nesting in Swallows. Science 224(4648): 518-519.

Brown CR, Brown MB, 2001. Avian Coloniality: progress and problems. In: Nolan V, Thompson CF, editors. Current Ornithology. $2^{\text {nd }}$ ed. New York: Springer US.

Brown $M$, Lawes $M, 2007$. Colony sze an nest density predict the likelihood of parasitism in the colonial Southern Red Bishop Euplectes orix - Diderick Cuckoo Chrysococcyx caprius system. Ibis, 149(2):321-327.

Buckleton J, Triggs CM, Walsh SJ, 2005. Forensic DNA Evidence Interpretation. Florida: CRC Press.

Burley N, 1986. Sexual selection for aesthetic traits in species with biparental care. The american naturalist, 127(4): 415 
Burley NT, Calkins JD, 1999. Sex ratios and sexual selection in socially monogamous zebra finches. Behavioral Ecology 10(6), 626-635.

Cevasco CM, Frere E, Gandini P, 2001. Intensidad de visitas como condicionante de la respuesta del pinguino de magallanes al disturbio humano. Ornitologia Neotropical, $12: 75-81$

Charnov EL, 1982. The theory of sex allocation. Princeton, New Jersey: Princeton University Press

Currie D, Burke T, Whitney R, Thompson D, 1998. Male and female behaviour and extra-pair paternity in the wheatear. Animal Behaviour, 55(3), 689-703.

Dakin EE, Avise JC, 2004. Microsaellite null alleles in parentage analysis. Heredity, 93(5): 504-509

Dantas GPM, Almeida VS, Maracini P, Serra SD, Chame M, Labarthe N, Kolesnikova C, Siciliano S, Matias CAR, Moura JF, Campos SD, Maders A, Serafini PP, 2013. Evidence fr northward extension of the winter range of Magellanic penguins along the brazilian coast. Marine Ornithology, 41:195-197

Dawson WR, O'Connor TP, 1996. Energetic features of avian thermoregulatory response. In Carey C, editor. Avian Energetics and Nutritional Ecology, pp. 85-124. New York: Chapman \& Hall

Dearborn DC, 2001. Body condition and retaliation in the parental effort decisions of incubating great frigatebirds (Fregata minor). Behav Ecol, 12:200-206.

Decker MD, Parker PG, Minchella DJ, Rabenold KN, 1993. Monogamy in black vultures: genetic evidence from DNA fingerprinting. Behav Ecol, 4: 29-35.

Dixon A, Ross D, O'Malley SLC, Burke T, 1994. Paternal investment inversely related to degree of extra-pair paternity in the reed bunting. Nature. 371:698-700

Dreiss AN, Silva N, Richard M, Moyen F, Thery M, Møller AP, Danchin E, 2008. Condition-dependent genetic benefits of extrapair fertilization in female blue tits Cyanistes caeruleus. J Evol Biol, 21:1814-1822.

Dunbrack RL, Coffin C, Howe R. 1995. The Cost of Males and the Paradox of Sex: An Experimental Investigation of the Short-Term Competitive Advantages of Evolution in Sexual Populations. Proc. R. Soc. B, 262 (1363):45-49.

Dunn PO, Cockburn A, 1999. Extrapair mate choice and honest signaling in cooperatively breeding superb fairy-wrens. Evolution. 53: 938-946 
Ellegren H, Gustafsson L, Sheldon BC, 1996. Sex ratio adjustment in relation to paternal attractiveness in a wild bird population. Proc. Natl. Acad. Sci. 93:1172311728

Emlen ST, Oring LW. 1977. Ecology, sexual selection, and the evolution of mating systems. Science, 197: 215-223.

Fisher RA, 1930. Genetical theory of natural selection. London: Clarendon Press.

Foerster K, Delhey K, Johnsen A, Lifjeld JT, 2003. Females increase offspring heterozygosity and fitness through extra-pair matings. Nature, 425:715-717.

Fowler GS. 1993. Ecological and endocrinological aspects of long-term pair bonds in the Magellanic penguin (Spheniscus magellanicus). $\mathrm{PhD}$ dss, University of Washington

Freeland JR. 2011. Molecular ecology. Chichester: John Wiley \& Sons.

Freeman A, Herron JC. 2009. Análise evolutiva. São Paulo: Artmed.

Frere E, Gandini P, Boersma PD, 1992. Effects of nest type and location on reproductive success of the Magellanic Penguin Spheniscus magellanicus. Marine Ornithology, 20:1-6.

Garvin JC, Abroe B, Pedersen MC, Dunn PO, Whittingham LA, 2006. Immune response of nestling warblers varies with extra- pair paternity and temperature. Molecular Ecology, 15:3833-3840.

Gilbert L, Burke T, Krupa A, 1998. No evidence for extra-pair paternity in the western gull. Molecular Ecology, 7:1549-1552

Goossens B, Graziani L, Waits L, 1998. Extra-pair paternity in the monogamous Alpine marmot revealed by nuclear DNA microsatellite analysis. Behavioral Ecology and Sociobiology, 43: 281-288.

Gowaty PA, 1985. Multiple parentage and apparent monogamy in birds. Ornithol Monogr, 37:11-21

Gowaty PA, 1996. Field studies of parental care in birds: new data focus questions on variation among females. In: Snowdon CT, Rosenblatt JS editors. Advances in the study of behavior. New York: Academic Press. p. 476-531.

Gowaty PA, Bridges WC, 1991. Behavioral, demographic, and environmental correlates of extrapair fertilizations in eastern bluebirds Sialia sialis. Behavavior Ecology, 2:339-350. 
Griffith S, Owens I, Thuman K. 2002. Extra pair paternity in birds: a review of interspecific variation and adaptive function. Molecular Ecology 11: 2195-2212.

Griffiths R, Double MC, Orr K, Dawson RJG, 1998. A DNA test to sex most birds. Molecular Ecology, 7:1071-1075.

Griggio M, Matessi G, Marin G, 2004. No evidence of extra-pair paternity in a colonial seabird, the commmon tern (Sterna hirundo). Italian Journal of Zoology, 71: 219-222

Gyllensten UBS, Jakobsson S, Temrin H, 1990. No evidence for illegitimate yong in monogamous na polyginous warblers. Nature, 343:168-170

Hasselquist D, Bensch S, von Schantz T, 1996. Correlation between male song repertoire, extra-pair paternity and offspring survival in the great reed warbler. Nature, 381:229-232.

Hill C, Gjerdrum C, Elphick C, 2010. Extreme levels of multiple mating characterize the mating system of the Saltmarsh Sparrow (Ammodramus caudacutus). The Auk, 127(2): 300-307.

Hood LC. 1996. Adrenocortical response to stress in incubating Magelanic penguins (Spheniscus magellanicus) and mate switching in Magelanic penguins at Punta Tombo, Argentina. MSc thesis, University of Washington.

Hornfeldt B, Hipkiss T, Fridolfsson AK, Eklund U, Ellegren H, 2000. Sex ratio and fledging success of supplementary-fed Tengmalm's owl broods. Molecular Ecology, 9:187-192

Hoset KS, Espmark Y, Moksnes A, Haugan T, Ingebrigtsen M, Lier M, 2004. Effect of ambient temperature on food provisioning and reproductive success in snow buntings Plectrophenax nivalis in the high Arctic. Ardea, 92:239-246

Hoset KS, Espmark Y, Fossoy F, Stokke BG, Jenson H, Wedege M, Moksnes A, 2013. Extra-pair paternity in relation to regional and local climate in an Arctic-breeding passerine. Polar Biology, 37: 89-97

Hunter F, Davis L, 1998. Female Adélie penguins acquire nest material from extrapair males after engaging in extrapair copulations. Auk, 115: 526-528.

Hunter F, Miller G, Davis L, 1995. Mate switching and copulation behaviour in the Adelie penguin. Behaviour, 132: 691-707.

Jeffreys AJ, Wilson V, Thein S, 1985. Hypervariable minisatellite regions in human DNA. Nature 314:67-73. 
Jennions $M$, Petrie $M, 2000$. Why do females mate multiply? A review of the genetic benefits. Biol Rev, 75: 21-64.

Johnsen, A. and Lifjeld, J. T. 2003. Ecological constraints on extra-pair paternity in the bluethroat. Oecologia, 136: $476-483$.

Johnson, LS, Thompson CF, Sakaluk SK, Neuhäuser M, Johnson BG, Soukup SS, Forsythe AJ, Masters BS, 2009. Extra-pair young in house wren broods are more likely to be male than female. Proc. Biol. Sci. 276: 2285-2289.

Jones, AG, Ardren WR, 2003. Methods of parentage analysis in natural populations. Molecular Ecology. 12:2511-2523.

Jones AG, Small CM, Paczolt KA, Ratterman NL, 2010. A practical guide to methods of parentage analysis. Molecular Ecology Resources, 10:6-30.

Kalinowski ST, Taper ML, Marshall TC, 2007. Revising how the computer program CERVUS accommodates genotyping error increases success in paternity assignment. Molecular Ecology, 16:1099-106.

Kalinowski ST, Wagner, AP, Taper ML, 2006. MI-Relate: a Computer Program for Maximum Likelihood Estimation of Relatedness and Relationship. Molecular Ecology Notes, 6: 576-579.

Kempenaers B, Andriaensen F, van Noordwijk AJ, Dhondt AA, 1996. Genetic similarity, inbreeding and hatching failure in blue tits: are unhatched eggs infertile? Proc R Soc Lond B, 263:179-18.

Kempenaers B, Verheyen GR, Dhondi AA. 1997. Extrapair paternity in the blue tit (Parus caeruleus): female choice, male charateristics, and offspring quality. Behavioral Ecology, 8: 481-492.

Kirkpatrick M, Ryan MJ, 1991. The evolution of mating preferences and the paradox of the lek. Nature, 8:481-492.

Kolliker M, Heeb P, Werner I, Mateman AC, Lessells CM, Richner H, 1999. Offspring sex ratio is related to male body size in the great tit (Parus major). Behavioral Ecology, 10: 68-72.

Komdeur J, Daan S, Tinbergen J, Mateman C, 1997. Extreme adaptive modification in sex ratio of the Seychelles warbler's eggs. Nature, 385:522-525.

Korpimaki E, MayCA, Parkin DT, Wetton JH, Wiehn J, 2000. Environmental and parental condition related variation in sex ratios of kestrel broods. Journal Avian Biology, 31: 128-134. 
Krackow S, 1995. Potential mechanisms for sex ratio adjustment in mammals and birds. Biol Rev, 70:225-241.

Lack D. 1968. Ecological Adaptations for Breeding in Birds. London: Methuen.

Leech D, Hartley I, Stewart I, Griffith S, Burke T, 2001. No effect of parental quality or extrapair paternity on brood sex ratio in the blue tit (Parus caeruleus). Behavior Ecology, 12: 674-680.

Lezalová-Pialková R, 2011. Molecular evidence for extra-pair paternity and intraspecific brood parasitism in the black-headed gull. J Ornithol, 152:291-295

Lifjeld JT, Laskemoen T, Fossøy F, Johnsen A, Kleven O, 2007. Functional infertility among territorial males in two passerine species, the willow warbler Phylloscopus trochilus and the bluethroat Luscinia svecica. Journal of Avian Biology, 38: 267-272.

Lorentsen SH, Amundsen T, Anthonisen K, Lifjeld JT, 2000. Molecular evidence for extrapair paternity and female-female pairs in a socially monogamous colonial seabird, the Antarctic petrel. Auk, 117:1050-1055.

Lynch M, Walsh B, 1998. Genetics and Analysis of Quantitative Traits. Sunderland, MA: Sinauer Associates.

Lyon BE, Everding S, 1996. High frequency of conspecific brood parasitism in a colonial waterbird, the Eared Grebe Podi- ceps nigricollis. Journal of Avian Biology, 27: 238-244.

Marshall TC, Slate J, Kruuk LEB, Pemberton JM, 1998. Statistical confidence for likelihood-based paternity inference in natural populations. Molecular Ecology, 7: 639-655.

Mauck RA, Waite TA, Parker PG, 1995. Monogamy in Leach's Storm petrel: DNA fingerprinting evidence. Auk 112:473-482

Mayer C, Pasinelli G, 2012. New support for an old hypothesis: density affects extrapair paternity. Ecology and Evolution, 3: 694-705.

McLean I, Kayes S, Murie J, 2000. Genetic monogamy mirrors social monogamy in the Fiordland Crested Penguin. New Zeal J, 27: 311-316.

Meagher TR, 1986. Analysis of paternity within a natural population of Chamaelirium luteum Identification of most-likely male parents. American Naturalist, 128: 199215. 
Møller AP, 1987. Mate guarding in the swallow Hirundo rustica: an experimental study. Behav Ecol Sociobiol, 21: 119-123.

Møller AP, 1998. Sperm competition and sexual selection. In: Birkhead TR, Møller AP, editors. Sperm Competition and Sexual Selection. San Diego: Academic Press. p. 5590 .

Moller AP, Birkhead TR, 1993. A pairwise comparative method as illustrated by copulation frequency in birds. American Naturalist, 139:644-656

Moreno J, Boto L, Fargallo JA, León A, Potti J, 2000. Short communications Absence of extra - pair fertilisations in the Chinstrap Penguin Pygoscelis antarctica. Journal of Avian Biology, 4: 580-583.

Morton ES, Stutchbury BJM, Howlett JS, Piper WH, 1998. Genetic monogamy in blueheaded vireos and a comparison with a sympatric vireo with extrapair paternity. Behavior Ecology, 9:515-524.

Mougeot $F, 2004$. Breeding density, cuckoldry risk and copulation behaviour during the fertile period in raptors: a comparative analysis. Anim Behav, 67: 1067-1076.

Nager RG, Monaghan P, Griffiths R, Houston DC, Dawson R, 1999. Experimental demonstration that offspring sex ratio varies with maternal condition. Proc. Natl. Acad. Sci. 96:570-573.

Olsson O, Bonnedahl J, Anker-Nilssen P, 2001. Mate switching and copulation behaviour in King Penguins. Journal of Avian Biology, 32(2): 139-145.

Pemberton JM, 2009 Wild pedigrees: the way forward. Proceedings of the Royal Society of London B, 275:613-621.

Petrie M, Doums C, Moller AP, 1998. The degree of extra-pair paternity increases with genetic variability. Proc. Natl. Acad. Sci. U. S. A. 95: 9390-9395.

Petrie M, Kempenaers B, 1998. Extra-pair paternity in birds: explaining variation between species and populations. Trends Ecol. Evol. 13: 52-58.

Pilastro A, Pezzo F, Olmastroni S, Callegarin C, Corsolini S, Focardi S, 2001. Extrapair paternity in the Adelie penguin Pygoscelis adeliae. Ibis, 143:681-684.

Pütz K, Ingham RJ, Smith JG, 2000. Satellite tracking of the winter migration of Magellanic penguins (Spheniscus magellanicus) breeding in the Falkland Islands. Ibis, 142: 614-622. 
Putz KA, Schiavini AR, Rey BH, Luthi A, 2007. Winter migration of magellanic penguins from southermost distributional range. Mar Biol, 152: 1227-1235.

Quillfeldt P, Masello JF, Segelbacher G, 2012. Extra-pair paternity in seabirds: a review and case study of Thin-billed Pachyptila belcheri. J. Ornithol. 153: 367-373.

Radford, A. N. \& Blakey, J. K. 2000 Is variation in brood sex ratios adaptive in the great tit (Parus major)? Behavior Ecology, 11, 294 -298.

Saino,N, Ellegren H, Møller AP, 1999. No evidence for adjustment of sex allocation in relation to paternal ornamentation and paternity in barn swallows. Molecular Ecology, 8: 399-406.

Sambrook, J. Russel, D. W. 2001. Molecular Cloning. 3rd edition. 3 vol. Cold Spring Harbor Laboratory Press, New York.

Schiavini A, Yorio P, Gandini P, Raya-Rey A, Boersma PD, 2005. Los pingüinos de las costas argentinas: estado poblacional y conservación. Hornero 20: 5-23.

Schlosser JA, Garner TJm Dubach JM, Mcelligott AG, 2003. Characterization of microsatellite loci in Humboldt penguin (Spheniscus humboldti) and crossamplification in other penguin species. Mol. Eco. Notes 3: 62-64.

Schlosser JA, Dubach JM, Garner TWJ, Araya B, Bernal M, Simeone A, Wallace RS, 2008. Evidence for gene flow differs from observed dispersal patterns in the Humboldt penguin, Spheniscus humboldti. Conservation Genetics, 10(4): 839-849.

Schmoll T, Dietrich V, Winkel W, Epplen JT,Lubjuhn T, 2003. Long-term fitness consequences of female extra-pair matings in a socially monogamous passerine. Proc. R. Soc. Lond. B, 270: 259-264.

Schulze-Hagen K, Swatschek I, Dyrcz A, Wink M, 1993. Multiple paternity in broods of aquatic warblers Acrocephalus paludicola: first results of a DNA fingerprinting study. J Ornithol, 134:145-154.

Schwartz M, Boness D, Schaeff C, 1999. Female-solicited extrapair matings in Humboldt penguins fail to produce extrapair fertilizations. Behavior Ecology, 10: 242-250.

Scolaro JA, Hall MA, Ximénez IM, 1983. The Magellanic Penguin: sexing adults by discriminant analysis of morphometric characters. The Auk, 100(1): 221-224.

Selander RK. 1972. Sexual selection and dimorphism in birds. The condor, 68(2):113151. 
Sheldon BC, 1994. Male Phenotype, Fertility, and the Pursuit of Extra-Pair Copulations by Female Birds. Proc. R. Soc. B Biol. Sci. 257: 25-30.

Sheldon BC, Andersson S, Griffith S C, Ornborg J, Sendecka J, 1999. Ultraviolet colour variation influences blue tit sex ratios. Nature, 402: 874-877.

Sheldon, BC, Ellegren $\mathrm{H}, 1996$. Offspring sex and paternity in the collared flycatcher. Proc. R. Soc. B, 263: 1017-1021.

Sick H, 1997. Ornitologia Brasileira. Rio de Janeiro: Editora Nova Fronteira.

Simeone A, Luna-Jorquera G, Bernal M, Garthe S, Sepúlveda F, Villablanca R, Ellenberg U, Contreras M, Muñoz J, Ponce T, 2003. Breeding distribution and abundance of seabirds on islands off north- central Chile. Revista Chilena de Historia Natural, 76:323-333

Sladen WJL, 1958. The pygoscelid penguins. II. The Adélie Penguin. Falkland Islands Dependencies Survey Scientific Reports 17:23-97.

Sorenson LG, 1992. Variable mating system of a sedentary tropical duck: the whitecheeked pintail (Anas bahamensis bahamensis). The Auk, 109(2): 277-292.

Spottiswoode C, Moller AP, 2004. Genetic similarity and hatching success in birds. Proceedings of the Royal Society B, 271:267-272.

Spurr, EB, 1975. Communication in the Adelie Penguin. In: Stonehouse, B, editor. The biology of penguins. London: Macmillan. p. 449-501.

St Clair C, 1995 Unfit mothers? Maternal infanticide in royal penguins. Anim. Behav. 50: 1177-1185.

Stokes DL, Boersma PD, 1998. Satellite tracking of Magellanic Penguin migration. Condor, 100: 376-381

Stokes DL, Boersma PD, 1998. Nest-site characteristics and reproductive success in Magellanic Penguins (Spheniscus magellanicus). Auk, 115: 34-49.

Stokes DL, Boersma P, 1999. Where breeding Magellanic penguins Spheniscus magellanicus forage: satellite telemetry results and their implications for penguin conservation. Mar. Ornithol. 27: 59-65.

Stutchbury BJ, Morton ES, 1995. The effect of breeding synchrony on extra-pair mating systems in songbirds. Behavior, 132:675-690. 
Svensson E, Nilsson J, 1996. Mate quality affects offspring sex ratio in blue tits. Proc R Soc Lond B, 263:357-361.

Tautz D, 1989. Hypervariability of simple sequences as a general source for polymorphic DNA markers. Nucleic acids research, 17(16): 6463-6471.

Thusius KJ, Dunn PO, Peterson KA, Whittingham LA, 2001. Extra-pair paternity is influenced by breeding synchrony and density in the common yellowthroat. Behavioral Ecology, 12(5): 633-639.

Trail P. 1985. The intensity of selection: intersexual and interspecific comparisons require consistent measures. American Naturalit, 126: 434-439.

Tregenza T, Wedell N, 2000. Genetic compatibility, mate choice and patterns of parentage: invited review. Molecular Ecology, 9:1013-1027.

Trivers RL, 1972. Parental investment and sexual selection. In: Campbell B. Sexual Selection and the Descent of Man 1871-1971. Chicago: Aldine. p. 136-179.

Trivers RL, Willard DE, 1973. Natural selection of parental ability to vary the sex ratio of offspring. Science, 179:90-92.

Tschirren B, Postma E, Rutstein AN, Griffith SC, 2012. When mothers make sons sexy: maternal effects contribute to the increased sexual attractiveness of extra-pair offspring. Proc. Biol. Sci. 279: 1233-1240.

Vaclav R, Hoi H and Blomqvist D, 2003. Food supplementation affects extrapair paternity in house sparrows (Passer domesticus) Behav. Ecol. 14: 730 -735

Vetter O, Magratg MJ, Velde MV, Komdeur J, 2013.Covariance of paternity and sex with laying order explains male bias in extra-pair offspring in a wild bird population. Biology letters, 9:15.

Wagner RH, Schug MD, Morton ES, 1996. Confidence of paternity, actual paternity and parental effort by purple martins. Animal Behavior, 52:123-132.

Weatherhead P J, Yezerinac SM, 1998. Breeding synchrony and extra-pair mating in birds. Behavioral Ecology and Sociobiology, 43(3): 217-219.

Warkentin IG, Curzon AD, Carter RE, Wetton JH, James PC, Oliphant LW, Parkin, DT, 1994. No evidence for extrapair fertilizations in the merlin revealed by DNA fingerprinting. Molecular Ecology, 3: 229-234.

Weatherhead PJ, Boag PT, 1995. Pair and extra-pair mating success relative to male quality in red-winged blackbirds. Behav Ecol Sociobiol, 37:81-91. 
Webster MS, Pruett-Jones S, Westneat DF, Arnold SJ, 1995. Measuring the effects of pairing success, extra-pair copulations and mate quality on the opportunity for sexual selection. Evolution, 49: 1147-1157.

Webster MS, Reichart L, 2005. Use of microsatellites for parentage and kinship analyses in animals. Molecular Evolution, 395: 222-238.

Webster MS, Westneat DF, 1998. The use of molecular markers to study kinship in birds: techniques and questions. In: Molecular approaches to ecology and evolution. Boston: Birkha

Westeneat, DF, 1987 Extra-pair fertilizations in a predominantly monogamous bird: genetic evidence. Animal Behavior, 35: 877 - 886.

Westneat DF, 1994. To guard mates or go forage: Conflicting demands affect the paternity of male Red-Wilged Blackbirds. The american Naturalist, 144(2): 343

Westneat DF, Sherman PW, 1997. Density and extra-pair fertilizations in birds: A comparative analysis. Behavioral and Sociobiology. 41 (4): 205-215.

Westneat DF, Sherman PW, Morton ML, 1990. The ecology and evolution of extrapair copulations in birds. In: Power DM. Current Ornithology. Vol 7. New York: Plenum. p. 331-369.

Westneat DF, Sherman PW, Morton ML. 2010. The ecology and evolution of extrapair copulations in birds. In: Westneat F, Fox CW. Evolutionary Behavioural Ecology. New York: Oxford University Press. p. 331-369.

Westerdahl H, Bensch S, Hansson B, Hasselquist D, Von Schantz T, 1997. Sex ratio variation among broods of great reed warblers Acrocephalus arundinaceus. Molecular Ecology, 6:543-548.

Whittingham L, Dunn PO, 2000. Offspring sex ratios in tree swallows: females in better condition produce more sons. Molecular Ecology, 9: 1123-9.

Wiebe KL, Bortolotti GR, 1992. Facultative sex ratio manipulation in American kestrels. Behav. Ecol. Sociobiol. 30: 379-386.

Wiley RH. 1974. Evolution of social organization and life-history patterns among grouse. Q.Rev. Biol. 49: 201-227

Williams GC, 1979. The question of adaptive sex ratio in outcrossed vertebrates. Proc R. Soc. Lond. B, 205:567-580. 
Williams TD, 1995. Magellanic Penguin. In: Perrins CM, Bock J, Kikkawa J, editors. The Penguins . New York: Oxford University Press Inc.

Wink M, Dyrcz A.1999. Mating systems in birds: a review of molecular studies. Acta Ornithol, 34: 91-109.

Wittenberger JF. 1979. The Evolution of Mating Systems in Birds and Mammals. In Marler P, Vandernbergh JG. Handbook of behavioral neurobiology. $3^{\text {rd }}$ ed. New York: Plenum Press. p. 271-349.

Wolf LL. 1975. 'Prostitution' behavior in a tropical humming-bird. Condor. 77: 140144.

Yom-Tov Y, 2001. An update list and some comments on the occurence of intraspecific nest parastism in birds. Ibis, 143: 133-143.

Yorio P, Boersma PD, 1994. Consequences of nest desertion and inattendance for Magellanic Penguin hatching success. Auk 111:215-218.

Zeh JA, Zeh DW, 2001. Reproductive mode and the genetic benefits of polyandry. Animal Behavior, 61:1051-1063. 